\title{
e-SCM: Internet's impact on supply chain processes
}

\author{
Cristina Giménez \\ Dpt. of Operations and Innovation Management \\ ESADE Business School-Universitat Ramon Llull \\ Avda. de Pedralbes 60-62; 08034-Barcelona, Spain \\ cristina.gimenez@esade.edu
}

Cristina is assistant professor in the Dpt. of Operations and Innovation Management at ESADE Business School. She holds a PhD in Business Administration from Universitat de Barcelona (Spain) and a MSc in Logistics and Supply Chain Management from Cranfield University (UK). Her teaching and research interests are Supply Chain Management (SCM), Logistics' integration processes and Green SCM. Her recent papers have been published in the International Journal of Production Research, the International Journal of Operations and Production Management, the Journal of Supply Chain Management, the International Journal of Physical Distribution and Logistics Management, the International Journal of Integrated Supply Management and the International Journal of Logistics Management. Cristina has teaching experience both in Operations Management and Supply Chain Management in undergraduate, graduate and in-company courses.

\author{
Helena R. Lourenço \\ GREL- IET, Department of Economics \& Business, \\ Universitat Pompeu Fabra \\ Ramon Trias Fargas, 25-27; 08005-Barcelona, Spain \\ helena.ramalhinho@upf.edu
}

Helena is associate professor in the Dpt. of Economics and Business at Universitat Pompeu Fabra. She holds a PhD and a MSc in Operations Research from Cornell University (USA). Her teaching and research interests are Operations Research, Production and Operations Management, Logistics, Metaheuristics, Combinatorial Optimization and Scheduling. Her recent papers have been published in the European Journal of Operational Research, Annals of Operations Research, Mathware and Soft Computing and Transportation Science. Helena has teaching experience both in Operations Management and Supply Chain Management in undergraduate, graduate and in-company courses. 


\title{
e-SCM: Internet's impact on supply chain processes
}

\begin{abstract}
Purpose - This paper analyses the interaction of two topics: Supply Chain Management (SCM) and the Internet. Merging these two fields is a key area of concern for contemporary managers and researchers. They have realised that the Internet can enhance SCM by making real time information available and enabling collaboration between trading partners.

Design/methodology/approach - A literature review in prestigious academic journals in Operations Management and Logistics has been conducted for the period 1995-2005. The objective is to collect, organise and synthesise existing knowledge relating to SCM and the Internet.

Findings - Our study has described the impact that the Internet has on the different processes that SCM embrace. The literature review undertaken on the topic has shown that e-SCM has been acknowledged as an outstanding topic in the supply chain literature in the most prestigious Operations Management and Logistics journals, especially after year 2000. The main topics have been e-procurement, e-fulfilment and information flows.
\end{abstract}

Originality/value - The value of this paper is to define e-SCM, to analyse how research in this area has evolved during the period 1995-2005 and to identify some lines of further research.

Keywords - e-Supply Chain Management, Internet, e-SCM

Paper type - Literature review 


\section{Introduction}

Enhanced competitiveness requires that companies ceaselessly integrate within a network of organisations. Firms ignoring this challenge are destined to fall behind their rivals. This integration of companies within a network has led to put more emphasis on Supply Chain Management (SCM). "SCM is the management of upstream and downstream relationships in order to deliver superior customer value at less cost to the supply chain as a whole" (Christopher, 1998). The integral value of the SCM philosophy is that "total performance of the entire supply chain is enhanced when we simultaneously optimise all the links in the chain as compared to the resulting total performance when each individual link is separately optimised (Burke and Vakkaria, 2002).

Recent technological developments in information systems and information technologies have the potential to facilitate this coordination, and this, in turn, allows the virtual integration of the entire supply chain. The focus of this integration in the context of Internet-enabled activities is generally referred to as e-SCM. Merging these two fields (SCM and the Internet) is a key area of concern for contemporary managers and researchers. Managers have realised that the Internet can enhance SCM decision making by providing real-time information and enabling collaboration between trading partners. Many companies have implemented pointof-sales scanners, which read, on real time, what is being sold. These companies do not only collect information on real-time to make decisions about what to order or how to replenish the stores; they also send this information, through the Internet, to their suppliers in order to make them able to synchronise their production to actual sales.

The recent proliferation of papers on SCM and the Internet related topics explain the increasing interest of researchers for this area. There is a growing stream of literature attempting to better understand the impact of the Internet on different SCM activities (planning, distribution, design, etc.). However, there is a disjointed scattering of research activity that fails to clearly represent what should be understood by e-SCM, what we currently know about the effects of the Internet on SCM and what we still need to learn.

Many researchers have examined the work done in the field of Operations Management and SCM, see for example Prasad and Babbar (2000) and Pannirselvam, Ferguson et al. (1999). Although this type of papers is very useful to give insights on research directions, we have found so far only two literature reviews on the e-SCM topic: Johnson and Whang (2002) and Gunasekaran and Ngai (2004). Our paper follows the same methodology as these two papers, but it differs from them in the framework used to classify the papers. Johnson and Whang (2002) classified the papers into three categories: e-commerce, e-procurement and ecollaboration. Gunasekaran and Ngai (2004) classified the papers according to what they called the major components of IT-enabled SCM: strategic planning for IT in SCM, virtual enterprise and SCM, e-commerce and SCM, infrastructure for IT in SCM, Knowledge and IT management in SCM, and implementation of IT in SCM. The main objective in this paper is to identify the major issues surrounding the impact of the Internet on SCM, using a classification scheme and developing a framework based on the idea that SCM is the management of supply chain processes.

Given the importance of e-SCM and its impact on research and business, our motivation is to provide a literature review in a similar way as it has been done by the previous cited authors. The main objective of the present work is to provide practitioners and academicians with a comprehensive source of information to draw from, and help them identifying areas and directions for future work. 
The aim of this research is to consolidate the existing research efforts concerning the impact of the Internet on SCM, and to identify promising areas for study. In particular, the objectives of this study are:

1. To define what can be understood by e-SCM.

2. To determine if e-SCM has been acknowledged as an outstanding topic in the most prestigious Operations Management and Logistics journals.

3. To identify the main topics of e-SCM during the period 1995-2003.

4. To identify the methodologies used in the existing literature.

5. To present a literature review of the main topics on e-SCM.

6. To identify implications and directions for future research.

The work is organised as follows, in section 2 we present a definition of e-SCM. In section 3, we provide a description of the research methodology followed in this work. In section 4, we present a summary of the research results. In section 5, for each e-SCM topic, we provide a literature review and some directions for future research. And, finally, in section 6 we present some conclusions.

\section{Defining e-SCM}

As Croom (2005) pointed out very recently, there is some debate about the scope of SCM. For example, Oliver and Webber (1992) and Houlihan (1984) used the term SCM for the internal supply chain that integrates business functions involved in the flow of materials and information from inbound to outbound ends of the business. Ellram (1991) viewed SCM as an alternative to vertical integration. Cooper, Lambert et al. (1997) defined SCM as "the integration of key business processes from end user through original suppliers that provides products, services, and information that add value for customers and other stakeholders". And, Christopher (1998) defined SCM as the management of upstream and downstream relationships. Croom (2005) suggested that one way of dealing with the diversity of SCM definitions is to concentrate on the core processes and functions relating to the management of supply chains (for example, fulfilment, operations planning and procurement).

In the literature there is a diversity of models suggesting which are the main supply chain processes. For example, the Supply Chain Operations Reference (SCOR) model developed in 1996 focuses on five key processes: plan, source, make, deliver, and return. Cooper, Lambert et al. (1997) defined SCM taking into account the eight supply chain processes identified by the International Centre for Competitive Excellence (now named Global Supply Chain Forum): customer relationship management, customer service management, demand management, fulfilment, procurement, manufacturing flow management, product development and commercialisation, and reverse logistics.

Hewitt (1994) found that executives identify up to fourteen business processes. As a result, a definition comprising a number of processes closer to fourteen might provide more detailed information for practitioners and researchers. Accordingly, from the two previous models we decided to adopt the definition of SCM provided by Cooper, Lambert et al. (1997). This definition has been widely referred to (see for example, Romano and Vinelli, 2001; Cagliano, Caniato et al., 2003; Mills, Schmitz et al., 2004; Cousins, 2005; and Danese, Romano et al., 2006). 
Following the definition of SCM of Cooper, Lambert et al. (1997), we define e-SCM as the impact that the Internet has on the integration of key business processes from end user through original suppliers that provides products, services, and information that add value for customers and other stakeholders. The main objective of this paper is to identify the major issues surrounding the impact of the Internet on SCM, focusing on supply chain processes.

The Internet can have three main impacts on the supply chain. One of the most covered topics

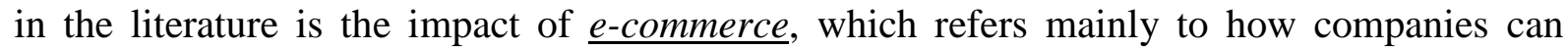
respond to the challenges posed by the Internet on the fulfilment of goods sold through the net. Another impact refers to information sharing, how the Internet can be used as a medium to access and transmit information among supply chain partners. However, the Internet not only enables supply chain partners to access and share information, but also to access data analysis and modelling to jointly make a better planning and decision making. This jointly planning and decision making is the third type of impact of the Internet on SCM and we refer to it as knowledge sharing ${ }^{\underline{1}}$.

The Internet can provide companies the ultimate benefits of reducing costs, improving service, enhancing customer satisfaction and retaining competitive advantage. These benefits derive from the impact of the Internet on different supply chain processes. The Internet enables companies to collaborate with business partners to improve forecasting and planning, which leads to stock and stock-out reductions (which means lower costs and improved service). This technology can also be used to communicate with the customer, leading to a better customer service. The Internet also enables companies to access and share data along the supply chain, making the fulfilment process more efficient. Web-based technologies can also have a positive impact on the manufacturing flow management, as the sharing of information about demand and supply capacity can make the product flow through the manufacturing facilities more efficient. The Internet can also improve the efficiency of the procurement process.

Although the implementation of web-based technologies possesses great potential for cutting costs and driving efficiencies, this process generates some cultural and technical concerns (Chou et al., 2004). Collaboration is based on the efforts of trust and commitment and cooperative norms; and it requires corporations to overcome the natural resistance to reveal business secrets to their partners (Chou et al., 2004). Regarding the technical concerns, the biggest ones stem from the insecure nature of the Internet and the challenge of application integration among trading partners (Chou et al., 2004).

\section{Research methodology}

\subsection{Journals chosen}

This paper reviews the literature in academic journals where Operations Management and Logistics academics and practitioners publish. Although there are some published books that include a comprehensive collection of research papers on the topic (see for example, Cheng, Webb et al., 2004; Simchi-Levi, Wu et al., 2004; Cheng, 2005; and Geunes, Akcali et al., 2005), this paper will focus on a review of research published on academic journals. The objective is to collect, organise and synthesise existing knowledge relating to SCM and the Internet. We have made a literature review of thirteen Operations Management and seven Logistics journals for the period 1995-2005. Operations Management journals have been

\footnotetext{
${ }^{1}$ In the Information Systems area the result of applying analysis, interpretation and modelling to information is known as knowledge
} 
chosen through the analysis of previous studies that classified and ranked the most significant Operations Management journals in both U.S. and Europe (Vokurka, 1996; Goh, Holsapple et al., 1997; Soteriou, Hadjinicola et al., 1999; Donohue and Fox, 2000; and Vastag and Montabon, 2002). The thirteen Operations Management journals selected are: California Management Review (CMR), Decision Sciences (DS), European Journal of Operational Research (EJOR), Harvard Business Review (HBR), Interfaces (INTERFACES), International Journal of Operations and Production Management (IJOPM), International Journal of Production Economics (IJPE), International Journal of Production Research (IJPR), Journal of Operations Management (JOM), Management Science (MS), Omega (OMEGA), Operations Research (OR) and Production and Operations Management (POM). Logistics journals have been chosen analyzing the reference list of Operations Management and Logistics articles; the most cited Logistics journals have been included in our analysis. These journals are: International Journal of Physical Distribution and Logistics Management (IJPDLM), Journal of Business Logistics (JBL), Journal of Enterprise Information Management (JEIM), Journal of Purchasing and Supply Management (JPSM), Journal of Supply Chain Management (JSCM), Supply Chain Management: An International Journal (SCM) and The International Journal of Logistics Management (TIJLM).

We started our analysis in 1995 because a taxonomy analysis carried out by Alfaro, Alvarez et al. (2002) permitted to determine that in 1995 just only about 2\% of published papers in prestigious Operations Management journals were dedicated to SCM. Also, the Internet is a recent information technology. As a result, the research dedicated to SCM and the Internet before 1995 must be very limited. Due to the existence of multiple words related to the topic, we spent substantial time in the traditional and electronic library system sorting through the academic and business journals reviewing titles, abstracts and manuscripts. The topics we used to search were: Internet, e-commerce, B2B, B2C, e-SCM, electronic supply chain and information technologies. In total we collected 174 articles.

\subsection{Classification methodology}

We classified the articles by topic areas and by research methodologies. In order to classify the papers by topic we developed a framework which is shown in figure 1. As previously stated, following the definition of Cooper, Lambert et al. (1997), e-SCM is defined as the impact that the Internet has on the integration of key business processes from end user through original suppliers that provides products, services, and information that add value for customers and other stakeholders. As a result, a set of topics are related to the processes proposed by Cooper, Lambert et al. (1997): customer relationship management, customer service management, demand management, e-fulfilment, e-procurement, manufacturing flow management, product development and commercialisation, and reverse logistics. These set of topics are represented in Figure 1 under the concept of SCM processes. In section 5, we describe in detail each one of these topics. 


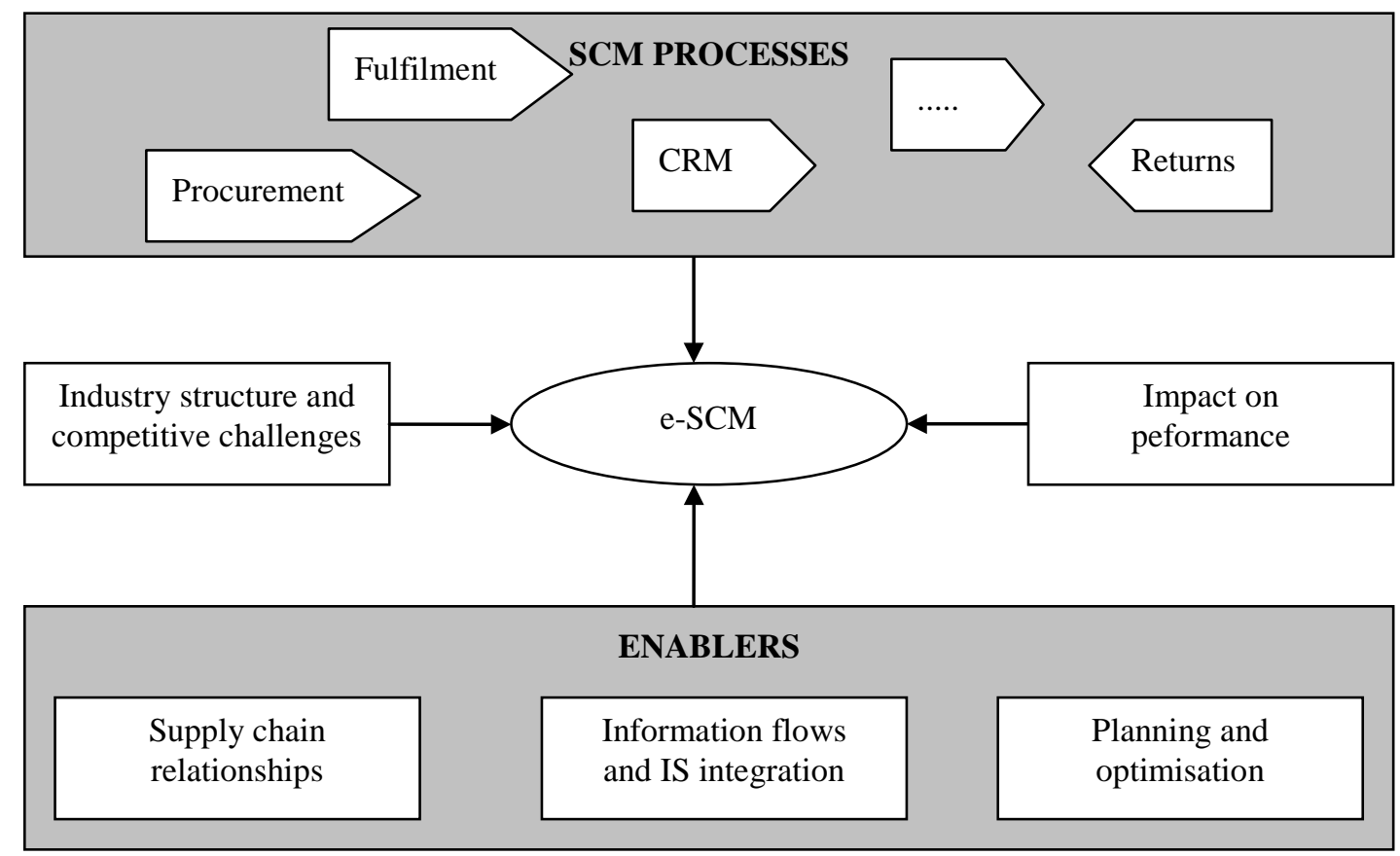

Figure 1. A framework for e-SCM

Although we were interested on focusing on the impact of the Internet on the supply chain processes identified by Cooper, Lambert et al. (1997), in our classification we added some topics that are related with SCM enablers, such as supply chain relationships, planning and optimisation tools and information flows. The topic of supply chain relationships was used to classify the papers that analyse the impact of the Internet on the management of supply chain relationships. The papers classified under the planning and optimisation topic are the ones that apply planning and optimisation systems based on decision models and technologies to several SCM processes. And, information flows comprises the papers that describe how information flows along the supply chain by means of Internet technologies.

Finally, we added two topics: industry structure and competitive challenges, and impact on performance. The first refers to the impact of the Internet on the industry structure and how companies are responding to competitive challenges using the Internet, and the latter refers to the impact of e-SCM on performance.

In order to classify the papers according to the methodology, we used four categories: conceptual, literature review, empirical and decision models. In the conceptual category we classified all papers that describe or present an aspect of e-SCM. In the literature review category we classified the papers whose main objective was to present a review of the work done on a specific topic. In the empirical category we considered the papers based on the results of case studies, surveys or web scans. And, finally, in the decision models category we classified all papers that apply decision technologies, such as mathematical and optimisation models, exact and heuristic solution methods, simulation, economic models, game theory, etc., to help managers to make better decisions.

In order to classify the papers and minimise questions in this process, we listed the possible subtopics by topic. However, we still found some papers whose classification was not easy. In these cases, all the authors were conferred and discrepancies were discussed until a consensus was reached.

When we were addressing the classification according to the methodology used in each paper, we realised that researchers sometimes use more than one methodology. In these cases, we identified all the methods and tried to determine the main contribution of each one to the 
achievement of the objective of the paper. We, therefore, classified the paper in the methodology category according to the methodology that contributed most to the objective of the paper. For example, one of the papers developed a web dynamic Available-To-Promise system and tested it in a case study. This paper was classified in the decision models category because the main objective of the paper was to develop the system.

\section{Research results}

In this section we analyse the information obtained and provide answers to the following research questions: 1) Has e-SCM been acknowledged as an outstanding topic in the literature in the most prestigious journals of Operations Management and Logistics? 2) Which are the eSCM topics covered in the most prestigious journals of Operations Management and Logistics? and 3) Which is the methodological profile followed by the e-SCM papers published in the most prestigious Operations Management and Logistics journals? In section 5 , for the impact of the Internet on each supply chain process we present a literature review and identify some lines of further research.

\subsection{Has e-SCM been acknowledged as an outstanding topic in the literature in the most prestigious journals of Operations Management and Logistics?}

Table I shows the distribution of articles along the time and the journals. As it can be appreciated in Table I, the total number of papers related to e-SCM topics in the Operations Management and Logistics journals has increased considerably. In the 1995-1999 period, there were only twelve articles while after the year 1999 the number of papers published by year increased considerably. Only in one year (2000) the number of papers published was similar to the number of papers published during the previous five-year period (1995-1999). And, during the last three years of the period analysed (2003 to 2005) more than thirty papers per year have been published. The increase in the number of e-SCM papers has been bigger in the Operations Management journals than in the Logistics journals. This demonstrates that the e-SCM topic has gained importance in the research agenda, especially in the Operations Management journals. From the twelve articles published during the first period (1995-1999), there are only two papers published in 1995 and three papers published during the year 1996 . This suggests that the starting year of the interval object of our research (1995) can be justified.

For each journal, Table I shows the total number of papers related to the e-SCM topics in absolute and relative terms. In absolute terms the journals with a highest number of e-SCM papers published are: SCM, IJPDLM and MS. In relative terms (approximate percentage of eSCM papers over the total number of papers published), the journals with a highest percentage are, as expected, some Logistics journals: SCM, JSCM, IJPDLM and JPSM. It has also to be pointed out that the rest of the Logistics journals have a higher percentage than most of the Operations Management journals. Only CMR and POM have a higher percentage than the Logistics journals with the lowest scores (JBL, JEIM and TIJLM). 
Table I. Articles per journal

\begin{tabular}{|c|c|c|c|c|c|c|c|c|c|}
\hline Journal & $\begin{array}{c}1995- \\
1999\end{array}$ & 2000 & 2001 & 2002 & 2003 & 2004 & 2005 & $\begin{array}{c}\text { Total } \\
\text { papers }\end{array}$ & $\begin{array}{c}\text { \% over total } \\
\text { papers }\end{array}$ \\
\hline \multicolumn{10}{|c|}{ OM/OR JOURNALS } \\
\hline CMR & 1 & 1 & & 2 & 1 & 1 & 3 & 9 & $2,76 \%$ \\
\hline DS & & & & 1 & & & 2 & 3 & $0,81 \%$ \\
\hline EJOR & & & & & 2 & 5 & 5 & 12 & $0,27 \%$ \\
\hline HBR & 1 & 2 & & & & & & 3 & $0,37 \%$ \\
\hline INTERFACES & & & 4 & 1 & 2 & & 1 & 8 & $1,47 \%$ \\
\hline IJOPM & 1 & & 2 & & 3 & 2 & 3 & 11 & $1,35 \%$ \\
\hline IJPE & & & & 6 & 2 & 4 & & 12 & $0,73 \%$ \\
\hline IJPR & & 1 & 2 & & 4 & 1 & 2 & 10 & $0,41 \%$ \\
\hline JOM & 1 & & & 2 & 1 & 1 & 2 & 7 & $1,88 \%$ \\
\hline MS & & 1 & & 1 & 6 & 2 & 7 & 17 & $1,25 \%$ \\
\hline OMEGA & & & & & 1 & 1 & & 2 & $0,46 \%$ \\
\hline OR & & & & & & & & $\mathbf{0}$ & $0,00 \%$ \\
\hline POM & & & & 4 & & 3 & & 7 & $3,10 \%$ \\
\hline TOTAL OM & 4 & 5 & 8 & 17 & 22 & 20 & 25 & 101 & \\
\hline \multicolumn{10}{|c|}{ LOGISTICS JOURNALS } \\
\hline IJPDLM & 2 & 3 & 4 & 4 & 1 & 2 & 1 & 17 & $3,80 \%$ \\
\hline JBL & & & & & 2 & 1 & 2 & 5 & $2,09 \%$ \\
\hline JEIM (LIM) & & & 1 & & 3 & 4 & 2 & 10 & $2,46 \%$ \\
\hline JSCM & & 1 & 2 & 1 & & 1 & 2 & 7 & $4,70 \%$ \\
\hline JPSM (EJPSM) & 2 & & & 2 & 1 & 2 & 1 & 8 & $3,64 \%$ \\
\hline SCM & 2 & 1 & 3 & 3 & 3 & 4 & 6 & 22 & $7,64 \%$ \\
\hline TIJLM & 2 & 1 & & & & 1 & & 4 & $2,34 \%$ \\
\hline TOTAL LOG. & 8 & 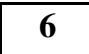 & 10 & 10 & 10 & 15 & 14 & 73 & \\
\hline TOTAL & 12 & 11 & 18 & 27 & 32 & 35 & 39 & 174 & \\
\hline
\end{tabular}

4.2. Which are the e-SCM topics covered in the most prestigious journals of Operations Management and Logistics?

Table II shows the topics used to classify the articles and the number of papers published on each one. As it can be appreciated in this table, the topics more covered by the existing literature are: e-procurement, e-fulfilment and information flows. The topics least covered are: demand management, customer relationship management, customer service management, and returns and reverse logistics. If we had included Marketing journals in our analysis we would probably have found a higher number of papers under the demand management, customer relationship management and customer service management topics. What is surprising is the reduced number of papers covering the impact of the Internet on the returns and reverse logistics process despite the increasing importance of this process. However it must be 
pointed out that the papers on the impact of the Internet on the reverse logistics are quite recent. We expect to find more papers covering this topic on the future. Other processes that require further study are the manufacturing flow and the product development processes, as they have also been covered by few papers. Nine papers have analysed the impact of the Internet on several supply chain processes and we expect a higher number of papers under this topic in the near future. Regarding the impact of the Internet on the performance and the industry structure, few papers have considered these topics and most of the existing papers on this topic have been published very recently.

Table II. Taxonomy analysis

\begin{tabular}{|c|c|c|c|c|c|c|c|c|}
\hline TOPIC & $\begin{array}{c}\text { Total number } \\
\text { of papers }\end{array}$ & 1995-1999 & 2000 & 2001 & 2002 & 2003 & 2004 & 2005 \\
\hline Customer relationship management & 4 & & 1 & & 1 & & 2 & \\
\hline Customer service management & 3 & & & & 1 & 2 & & \\
\hline Demand management & 1 & 1 & & & & & & \\
\hline e-fulfilment & 28 & 1 & 1 & 5 & 3 & 7 & 3 & 8 \\
\hline Manufacturing flow management & 6 & & & 3 & & 1 & 2 & \\
\hline e-procurement & 52 & 3 & 6 & 2 & 8 & 12 & 11 & 10 \\
\hline $\begin{array}{l}\text { Product development and } \\
\text { commercialization }\end{array}$ & 7 & 1 & 2 & 1 & & 2 & & 1 \\
\hline Reverse logistics and returns & 4 & & & & & 2 & 2 & \\
\hline Several supply chain processes & 9 & & & & 2 & 1 & 3 & 3 \\
\hline Supply chain relationships & 11 & 1 & & 2 & 3 & 1 & 1 & 3 \\
\hline Information flows & 28 & 4 & & 1 & 6 & 1 & 7 & 9 \\
\hline Planning \& optimisation & 7 & & & 4 & 1 & 2 & & \\
\hline $\begin{array}{l}\text { Industry structure and competitive } \\
\text { challenges }\end{array}$ & 7 & 1 & 1 & & & & 2 & 3 \\
\hline Impact on performance & 7 & & & & 2 & 1 & 2 & 2 \\
\hline Total & 174 & 12 & 11 & 18 & 27 & 32 & 35 & 39 \\
\hline
\end{tabular}

4.3. Which is the methodological profile followed by the e-SCM papers published in the most prestigious Operations Management and Logistics journals?

Table III shows the research methodologies used in the papers contained in our database. The methodologies most used by the existing papers are empirical (surveys and case studies), decision models and conceptual. Each one of these methodologies was used approximately by one third of the papers. Only seven out of the 174 papers analysed conducted a literature review and only two of them focused on the impact of the Internet on SCM. This highlights the need of a study like the one we provide in this paper, as it tries to clearly represent what we currently know about the effects of the Internet on SCM and what we still need to learn.

The conceptual methodology has been used in almost all the topics. The literature review methodology has been used to analyse e-procurement, product development, several supply chain processes simultaneously, and planning and optimisation. All the topics, except demand management, and planning and optimisation have been analysed through an empirical methodology. Decision models have also been used in most of the topics (the topics not covered by this methodology have been the industry structure and the ones more related with 
the Marketing area: customer relationship management, customer service management and demand management). In section 5, for each topic we provide an analysis of the methodologies used and identify further lines of research.

Table III. Research methodology

\begin{tabular}{|c|c|c|c|c|c|c|c|}
\hline \multirow[t]{2}{*}{ TOPIC } & \multirow{2}{*}{$\begin{array}{c}\text { Conceptual } \\
\text { and } \\
\text { frameworks }\end{array}$} & \multirow{2}{*}{$\begin{array}{l}\text { Literature } \\
\text { Review }\end{array}$} & \multicolumn{3}{|c|}{ Empirical } & \multirow{2}{*}{$\begin{array}{l}\text { Decision } \\
\text { Models }\end{array}$} & \multirow[b]{2}{*}{ Total } \\
\hline & & & $\begin{array}{l}\text { Case } \\
\text { Study }\end{array}$ & Survey & $\begin{array}{l}\text { Web } \\
\text { scan }\end{array}$ & & \\
\hline $\begin{array}{l}\text { Customer relationship } \\
\text { management }\end{array}$ & 2 & & 1 & 1 & & & 4 \\
\hline $\begin{array}{l}\text { Customer service } \\
\text { management }\end{array}$ & & & 1 & 1 & 1 & & 3 \\
\hline Demand management & 1 & & & & & & 1 \\
\hline e-fulfilment & 5 & & 2 & 8 & 2 & 11 & 28 \\
\hline $\begin{array}{l}\text { Manufacturing flow } \\
\text { management }\end{array}$ & 2 & & 1 & & & 3 & 6 \\
\hline e-procurement & 16 & 3 & 2 & 10 & 1 & 20 & 52 \\
\hline $\begin{array}{l}\text { Product development and } \\
\text { commercialization }\end{array}$ & 1 & 1 & 2 & & & 3 & 7 \\
\hline Reverse logistics and returns & & & 1 & & & 3 & 4 \\
\hline $\begin{array}{l}\text { Several supply chain } \\
\text { processes }\end{array}$ & 2 & 2 & 2 & 2 & & 1 & 9 \\
\hline Supply chain relationships & 6 & & 3 & 1 & & 1 & 11 \\
\hline Information flows & 9 & & 10 & 4 & & 5 & 28 \\
\hline Planning \& optimisation & 3 & 1 & & & & 3 & 7 \\
\hline $\begin{array}{l}\text { Industry structure and } \\
\text { competitive challenges }\end{array}$ & 3 & & 4 & & & & 7 \\
\hline Impact on performance & & & 1 & 5 & & 1 & 7 \\
\hline Total & 50 & 7 & 30 & 32 & 4 & 51 & 174 \\
\hline
\end{tabular}

In the appendix, we provide a table showing the papers classified under each topic and the methodology followed in each paper.

\section{Literature review and classification}

In this section, for each one of the supply chain processes we provide an analysis of the impact of the Internet on it, a summary of the existing studies and some directions for further research. The analysis of the remaining topics (Supply chain relationships, Information flows, Planning \& optimisation, Industry structure and competitive challenges and Impact on performance) is covered in another paper.

\subsection{The customer relationship management process}

The customer relationship management (CRM) process provides the structure for how the relationship with the customer is developed and maintained (Croxton, García-Dastugue et al., 2001). This process includes identifying key customers, segmenting them and tailoring products and services to their needs. The process also includes all activities related to working 
with customers in order to (1) improve processes, (2) eliminate demand variability and nonvalue added activities, and (3) develop agreements of metrics.

What is the impact of the Internet on this supply chain process? We can distinguish two different types of impacts: Internal and downstream. Internal effects refer to the impact of the Internet on the focal company. For example, through the Internet, all business units can have access to the same information about each customer. This means that all business units will be able to negotiate and relate with customers taking into account the same information.

The downstream effects refer to the impact of the Internet on the relationships with customers. One of the most important aspects of the downstream effects is that web sites allow companies to collect data as users navigate around them. This means that the Internet can generate a large amount of data, which can be very useful to CRM if it is analysed properly with Operations Research (OR) models (Geoffrion and Krishnan, 2001; Sodhi, 2001). This has motivated the development of OR-based tools for predicting individual consumers' purchasing behaviours, leading to improvements in forecasting and inventory deployment (Sodhi, 2001). Another downstream effect of the Internet is that it allows companies to provide new services to customers, increasing the companies' products and services offerings.

Boyer, Hallowell et al. (2002) and Småros, Holmström et al. (2000) cover the downstream effect related to increasing the products and services offerings. Scullin, Fjermestad et al. (2004) review the downstream effect of the impact of the Internet on the relationships with customers and the internal effect of how to manage the customer information within the company. Finally, Tsikriktsis, Lanzolla et al. (2004) review the antecedents of the adoption of e-CRM. The papers of Geoffrion and Krishnan (2001) and Sodhi (2001), which cover the aspect related to the analysis of the data gathered through the Internet, have not been classified here because they describe some OR tools for planning and optimising different processes (and not only the CRM process).

Further research regarding this process should try to analyse how different business units can use the same customer data. Future research should also try to determine what specific type of integration alternatives are available for organisations working with rapidly changing CRM and SCM support technologies. Future studies should also develop decision and OR tools to analyse the large amount of data gathered through the Internet. And, finally, researchers should also provide more empirical studies showing how the Internet is used to provide different product and service offerings (as it can be appreciated in Table IA in the appendix only one of the existing papers related this topic is empirically based).

\subsection{The customer service management process}

The customer service management process provides the firm's face to the customer (Croxton, García-Dastugue et al., 2001). It should be the single source of information to the customer. Real-time information is provided to the customer through interfaces with the firm's functions, such as operations and logistics (Croxton, García-Dastugue et al., 2001). This process includes strategic aspects, such as the development of the response procedures and the establishment of the infrastructure needed to respond. The process also includes tactical aspects, such as the recognition of the events that require a response, the implementation of the responses and the control of the process.

The most important impacts of the Internet on this process are in the internal and downstream parts of the supply chain. In the downstream part of the supply chain, the Internet can be used (1) to recognize events and listen to the customer, and (2) to communicate the response procedure to the customer. In the internal part of the process, the Internet can be used to 
enable information sharing on real time among different business units and among different functional areas of a firm. This internal information sharing will improve the response of the company to any event.

Ellinger, Lynch et al. (2003) and Rae-Smith and Ellinger (2002) cover the downstream part of the process, showing some examples of how companies communicate with their customers through the Internet. Papathanassiou, Kardaras et al. (2003) cover not only the downstream part of the customer service management process but also the internal one. All three papers are empirically based and cover the information sharing impact of the Internet. Further research should follow the perspective of Papathanassiou, Kardaras et al. (2003) in order to analyse intra-organisational and inter-organisational effects simultaneously. Cases showing how different business units share information on real time to provide a better customer service will be very valuable.

\subsection{The demand management process}

The demand management process needs to balance the customers' requirements with the firm's supply capabilities (Croxton, García-Dastugue et al., 2001). This includes forecasting demand and synchronising it with distribution, production and procurement.

The Internet impacts this process along all the supply chain. Information sharing about actual sales enables companies to improve their forecasts. This affects the internal part of the supply chain (the focal company), but it also affects its upstream and downstream links. For example, in the grocery industry a manufacturer can receive information about the actual sales of its products at the stores. Internally, this information sharing can improve its forecasts, leading to an improvement in production planning and a reduction in stock levels. Downstream, this information sharing enables the customer (the grocery company) to eliminate the replenishment orders, because replenishment decisions can be made by the manufacturer. This means that the grocery customer reduces its order process costs and the stock levels (because its supplier's forecasts are better and stock-outs have decreased). Upstream, the information obtained about actual sales can be also shared with the focal company's suppliers. This improves the suppliers' forecasts, leading to an improvement in their production planning and a reduction in stocks.

The Internet affects this process along the supply chain, not only on the information sharing aspect, but also on the knowledge sharing aspect. The Internet not only enables the supply chain partners to access and share information, but also to access data analysis and modelling to jointly make a better planning and decision making. Decision technologies that offer the access to this knowledge, or the tools to obtain it, will become an important issue in the future (Swaminathan and Tayur, 2003; Sodhi, 2001). One example of this knowledge sharing is Collaborative Planning Forecasting and Replenishment (CPFR). In these programs, customer, focal company and supplier do not only share information, they also plan together. In a CPFR program a forecasting support system is hold on an Internet server. This support system is updated with data from actual sales and other information provided by the grocery company and the manufacturer and provides the forecasts to the grocery retailer, the manufacturer and its suppliers. In September 1999, Henkel and Eroski (a Spanish grocery retailer) initiated a CPFR program. It resulted in an important improvement in the forecasts of both companies. Before implementing the program, half of the forecasts had a forecasting error higher than $50 \%$. Nine weeks after the implementation of the program, $75 \%$ of the sales forecasts had an error lower than 20\% (Jouenne, 2000). 
We only found one paper analysing the impact of the Internet on this process. McGuffog and Wadsley (1999) cover the information and knowledge share aspects of the Internet and consider the effects of e-commerce and collaborative planning on the supply chain. Further research should consider empirical analysis to determine the level of implementation of collaborative planning (such as CPFR) and collaborative replenishment (such as CRP) systems in different industries and the effects of this knowledge sharing on the performance of the supply chain. Collaborative planning includes the forecasting aspect of the demand management process, while collaborative replenishment covers the synchronisation part of this supply chain process. Research on decision models that can help managers to make collaborative planning along the supply chain is also needed. We think that multi-decision models which consider the objectives of different companies will play an important role in these decision and planning systems.

\subsection{The e-fulfilment process}

Order fulfilment is related with the effective management of all the activities needed to deliver the order to the customer. At the strategic level, there exists the need to design an efficient supply chain to enable a timely and accurate order fulfilment. At the operational level, the order fulfilment process consists on defining the following activities: generating, communicating, entering, processing, picking and delivering customer orders (Croxton, García-Dastugue et al., 2001). In a way, this process is about the integration of the manufacturing, logistics and marketing functions to ensure customer satisfaction and reduce total cost before, during and after the order fulfilment.

The impact of the Internet on the order fulfilment process has two main aspects. The first one is related to e-commerce and consists on fulfilling the customer orders placed through the Internet. While for customers the Internet has made the placement of orders more efficient, for the selling companies (of physical goods) the order fulfilment has become a critical operation (it is very costly and it is a key operation to obtain customer satisfaction). Lee and Whang (2001) comment that to obtain an efficient order-fulfilment, new innovative strategies based on a good use of information and leveraging of existing resources must be applied.

The second aspect is related to the use of the Internet to improve the efficiency of the order fulfilment process for both online and offline businesses. The order fulfilment process requires the access and manipulation of a large amount of data, from customer orders to inventory levels. Therefore, the advantage of accessing and sharing data along the supply chain using Internet technologies can make this process more efficient and less costly. The possibility of all partners in a supply chain to see customer orders on real-time, or near realtime, can lead to a significant reduction of variability and costs and, at the same time, improve the responsiveness of the firm. However, firms can go a little further and use this data to generate knowledge by applying sophisticated analytical tools to anticipate changes and be better prepared to respond to customers' demand. At the operational level, these tools can go from statistical forecasting methods to analyse customer orders, to inventory systems to obtain the optimal inventory, and/or to vehicle routing systems to design the most efficient delivery routes. And, at the strategic level, these analytical tools can be used to design the most efficient supply network.

In the literature review regarding the fulfilment process, one of the most covered impacts is how to deliver the goods sold through the e-commerce channel. This impact has been studied by the following authors: Punakivi, Yrjölä et al. (2001), Kämäräinen (2001), Kotzab and Madlberger (2001), Gurãu, Ranchhod et al. (2001), Delfmann, Albers et al. (2002), Marinus and De Koster (2002), Boyd, Hobbs et al. (2003), Da Silveira (2003), Starr (2003), 
Rabinovich (2004), Rabinovich and Bailey (2004), Boyer and Hult (2005), Dadzie, Chelariu et al. (2005), Rabinovich (2005) and Thirumalai and Sinha (2005).

The impact of information sharing on this process has been covered by six papers: Crowley (1998), Lee (2002), Kelleher, El-Rahalibi et al. (2003), Tyan, Wang et al. (2003), Rabinovich and Evers (2003) and Vannieuwenhuyse, Gelders et al. (2003). Lee (2002) describes how information sharing can lead to a more efficient supply chain. Crowley (1998), Kelleher, ElRahalibi et al. (2003) and Vannieuwenhuyse, Gelders et al. (2003) focus on the impact of information sharing on transportation decisions such as routing and mode selection. Rabinovich and Evers (2003) study the effects of information exchange on fulfilment activities, in particular on inventory decisions. And finally, Tyan, Wang et al. (2003) analyse freight consolidation policies under an e-business model.

Finally, some authors analyse how to design an efficient supply chain and the most appropriate distribution strategy in an Internet context. Dewman, Freimer et al. (2000) discuss distribution strategies in the information goods industry, while Yrjölä (2001) focuses on the food and grocery industries. Tsay and Agrawal (2004), Kevin Chiang and Monahan (2005) and Alptekinoglu and Tang (2005) analyse the impact of different distribution strategies for traditional and online retail stores. Nagurney, Cruz et al. (2005) develop a supply chain equilibrium model for a supply chain consisting of manufacturers, distributors and retailers with electronic commerce. And, finally, Piramuthu (2005) presents a framework for an automated supply chain configuration that takes advantages of the fast communication over the Internet.

The directions for further research can enter into one of the following categories: (1) better use of information and the creation of knowledge by using actual and new analytical and decision tools; (2) new strategies applied to the e-fulfilment activities; and (3) more empirical research work, including case studies and business models about the implementation of efulfilment.

With respect to the first line of further research, the access to more data and information will put more emphasis in global optimisation along the entire supply chain, instead of the usual models that focus on local optimisation. More work considering the global supply chain is expected in this area. Also, more models using multi-criteria decision making that reflect the integration and collaboration aspects of the e-fulfilment process should be the subject of future work.

Regarding the study of new strategies for the e-fulfilment activities, one problem that seems to need more research is the so-called last mile. New delivery solutions or strategies that can combine profitability and service are still needed. The use of knowledge management, operations research and simulation techniques will be a must in the solution of this important problem of the e-commerce for physical goods. Further research should also focus on empirical studies, as very few papers on this process are field-based.

\subsection{The manufacturing flow management process}

The manufacturing flow management process deals with making the products and establishing the manufacturing flexibility needed to serve the target markets (Croxton, GarcíaDastugue et al., 2001). The process includes all activities necessary for: (1) managing the product flow through the manufacturing facilities, and (2) obtaining, implementing and managing flexibility (Croxton, García-Dastugue et al., 2001). 
The Internet can have a positive impact on both aspects of the manufacturing flow management process. On one hand, the Internet provides the opportunity for demand and supply capacity data to be visible to all companies within a manufacturing supply chain, and therefore, the product flow through the manufacturing facilities can be improved. This visibility allows companies to be in a position to anticipate demand fluctuations and respond accordingly. The main effect of that is to reduce stocks and compress lead times. On the other hand, the Internet allows companies to be more flexible to respond to changes in demand. The Internet reduces the production cycles due to an increase in the speed of communication. "Companies like IBM, General Motors, General Electric and Boeing are assembling products for which the components are manufactured in many locations ... Using electronic bidding, assemblers get sub-assemblies up to 80 percent faster" (Gudmundsson and Walczuck, 1999).

The Internet impacts on the manufacturing flow management process along all the supply chain. On one hand, the Internet can have an impact on how a company manages the internal part of this process. For example, a company can implement an Internet-based production planning system to analyse the production requirements and plans of the different manufacturing facilities the company has. This system would improve the decision-making process of the production planners and sales personnel and would reduce planning inaccuracies. Xiong, Tor et al. (2003) and Abid, D'amours et al. (2004) develop decision models to improve customer satisfaction by sharing knowledge in the manufacturing flow management. They propose different collaborative planning systems which can be used jointly with other functional areas, such as sales and marketing. Ko, Kim et al. (2001) propose a system in which the central planning is developed in collaboration with external manufacturing partners with surplus capacity.

On the other hand, the Internet can have an impact on how the operations of the whole supply chain are managed. Kehoe and Boughton (2001a) and Kehoe and Boughton (2001b) suggest that the supply chain will change from an order-driven-lot-sizing approach to one more akin to a capacity-availability-booking approach supported by appropriate Internet search engines. And, Bruun and Mefford (2004) analyse the impact of the Internet on lean production systems.

Regarding the manufacturing planning and control systems, the academic challenges are to develop alternative business models, as well as to determine the tools and techniques by which the benefits from such models can be demonstrated to practitioners (Kehoe and Boughton, 2001a). Further research should also be more empirically based. Finally, researchers should develop more decision models that take into account the global aspects of the supply chain to help improving the manufacturing planning.

\subsection{The e-procurement process}

The procurement process relates a firm with its suppliers and it is a fundamental process in SCM. At the strategic level, the firm must define the corporate, manufacturing and sourcing strategies and identify the products and services that should be acquired from outside (Croxton, García-Dastugue et al., 2001). And, at the operational level, all the procurement activities, such as reviewing suppliers, identifying opportunities, and developing and implementing product or service agreements, should be developed and controlled (Croxton, García-Dastugue et al., 2001).

The e-procurement process supports the procurement and sourcing activities via Internet technologies and enables an efficient negotiation between buyers and suppliers. We distinguish two types of e-procurement: marketplaces and B2B. Marketplaces bring multiple 
buyers and sellers together in a virtual market, meanwhile B2B e-procurement is a one to one relationship.

Since the procurement or supplier relationship process consists on a relationship between businesses and needs a large amount of information sharing and transfer, the use of the Internet has had a big impact on this process. Several firms have implemented e-procurement solutions not only to reduce costs, but also to make more efficient this key process. The major impact of the Internet on the procurement process is certainly on information sharing, since this process involves retrieving, sharing and storing a large amount of data and information. However, knowledge sharing is becoming also a key issue in this process. Firms can apply analytical models to previous data and obtain important information to make better decisions (Swaminathan and Tayur, 2003).

We have subclassified the papers on this topic on 5 categories: general aspects of the use of the Internet on the procurement process, marketplaces, e-auctions, B2B procurement, and decision models for procurement decisions in an Internet environment. The general aspects of how firms use the Internet to streamline the process and which are the factors leading to a higher willingness to adopt Internet procurement have been covered by the following papers: Brenner and Hamm (1996), Min and Galle (1999), de Boer, Harink et al. (2002), Boyer and Olson (2002), Kaufmann and Carter (2002), Olson and Boyer (2003), Bartezzaghi and Ronchi (2004), Ordanini (2005) and Saeed, Malhotra et al. (2005). Croom (2000) also conducts an empirical study on the use of the Internet on the procurement process but he focuses on maintenance, repair, and operating (MRO) supplies.

The role and benefits of marketplaces have been covered extensively. Marketplaces are described by Gudmundsson and Walczuck (1999), Emiliani (2000), Kaplan and Sawhney (2000), Mahadevan (2000), Wise and Morrison (2000), Barratt and Rosdahl (2002), Emiliani and Stec (2002a) and Emiliani and Stec (2002b); and empirically analysed by Hohner, Rich et al. (2003), Mahadevan (2003), Bartezzaghi and Ronchi (2004) and Smart (2005). Essig and Arnold (2001) analyse the possibilities of marketplaces for buyers and develop an analytical framework. Finally, other authors, such as Grieger (2003) and Kleindorfer and Wu (2003) conduct a literature review on the topic of marketplaces.

The topic of auctions using the Internet has also been covered by several authors. See for example: Bapna, Goes et al. (2003), Carr (2003), Pinker, Seidmann et al. (2003), Snir and Hitt (2003), Emiliani and Stec (2004), Parente, Venkataraman et al. (2004), Talluri and Ragazt (2004), Teich, Wallenius et al. (2004), Easley and Tenorio (2004), Carare and Rothkopf (2005), Deltas and Engelbrecht-Wiggans (2005), Ding, Eliashberg et al. (2005) and Gunluk, Ladányi et al. (2005).

B2B e-procurement has been covered by some authors, however, it has not been so studied as the marketplace topic. Deeter-Schmelz, Bizzari et al. (2001) evaluate the impact of supplier support on buyers' adoption of the Internet for corporate-related purchasing activities while Calosso, Cantamessa et al. (2003) present an Internet platform for B2B procurement. Knudsen (2003) and Sparks and Wagner (2003) cover this topic from a descriptive point of view presenting main concepts and frameworks applied to different B2B procurement processes.

Finally, the application of decision models to e-procurement strategies and marketplaces has also a relevant presence in the literature. Authors like Lee and Whang (2002), Peleg, Lee et al. (2002), Wang and Benaroch (2004), Scott and Scott (2004), Seifert, Thonemann et al. (2004), Hazra, Mahadevan et al. (2004), Granot and Sošic (2005), Metty, Harlan et al. (2005) and Wu and Kleindorfer (2005) have developed decision models to help managers make decisions 
regarding procurement and pricing strategies, operating cost reductions of marketplaces, and the structure of the optimal portfolio of transactions.

Roberts and Mackay (1998) discuss how e-commerce may be used to support a portfolio of supplier relationships and use the case of BT Supply Management who has developed a supplier relationship framework to categorise suppliers and select the most appropriate eprocurement strategy. As the focus of this paper is more on matching supply chain relationship with the type of e-procurement tool, we have classified this paper under the supply chain relationship topic.

The e-procurement process is one of the most studied within the e-SCM literature. The topics most covered are marketplaces, auctions and the development of decision models for procurement decisions in an Internet environment. The benefits of using the Internet on the procurement processes have also been well analysed through empirical studies. However, we have identified some research gaps: More studies regarding the benefits and implementation barriers of using B2B procurement should be conducted. Further research should also compare the benefits of B2B with respect to the EDI technology. Also, more studies (like the one by Roberts and Mackay (1998)) should analyse how to strategically segment eprocurement strategies (for example, for which products/relationships are more suitable B2B applications and for which products/relationships are more appropriate marketplaces).

\subsection{The product development and commercialisation process}

The product development and commercialisation process is critical to the success of the firm. It is the set of activities that companies should undertake to successfully develop and launch products. According to (Croxton, García-Dastugue et al., 2001), this process includes the following subprocesses or activities: defining new products, establishing the cross-functional product development team, designing and building prototypes, determining the distribution channel for the new product, and measuring the process performance. The process includes integrating customers and suppliers into the product development in order to launch the right product and to reduce the time to market. For example, Microsoft used a web collaboration tool to bring the Xbox video game console to market two months ahead of schedule (Keenan and Ante, 2002).

What is the impact of the Internet on this process? One of the most important impacts is to enable collaboration among different functional areas and companies. Internet-based product development can make product design a truly collaborative process among designers, manufacturers, suppliers and customers without the limitations of geographical location and time zone (Cheng, Pan et al., 2000). Taking the perspective of a focal company, we can distinguish three types of effects: internal, downstream and upstream effects. Internal effects refer to the impact of the Internet on the focal company. The Internet enables the collaboration of different functional units in the new product development process. Downstream effects refer to the impact of the Internet on the relationships with customers: the Internet facilitates the involvement of customers and/or end-users in the design of new products, increasing the response of the company to the customer wants and needs. The company can also use the Internet to study the market in a faster and cheaper way. And, the upstream effects refer to the impact of the Internet on the relationships with suppliers: Suppliers can be involved in the process as early as possible in order to reduce costs and compress the time to market.

In the literature review on this topic, we found that the internal aspects were covered by Xie and Salvendy (2003) and Xie, Xu et al. (2005), while the upstream impacts were analysed by 
Elliman and Orange (2000) and the downstream ones by Finch (1999), Cheng, Pan et al. (2000) and Xie, Tu et al. (2001). Finally, Xie, Tu et al. (2003) presented a literature of the existing one-of-a-kind products systems and analysed the recent approaches of Internet-based design and manufacturing systems. They focused on Internet based-collaborative design along the supply chain, covering the internal, upstream and downstream effects.

The existing studies have covered the areas of information and knowledge sharing, and the upstream, internal and downstream perspectives. However, only one study, out of the seven found, is empirically based. Further research should put more emphasis on conducting empirical studies in order to determine the real use and advantages of using the Internet in the product development and commercialisation process.

\subsection{The reverse logistics and returns process}

Effective returns management is a key process in today's business. The returns policy is one of the most attractive tools to stay competitive (Rogers and Tibben-Lemke, 1999). This process includes all the elements in a supply chain and involves decisions on return avoidance practices, gate keeping, disposition guidelines, development of a returns network and flow options (Croxton, García-Dastugue et al., 2001).

How can the Internet help this process? Managing returns involves managing different types of data: reasons for return (defective, in warranty, old, etc.), conditions of the product, point of return, instructions to customers, etc. The major impact of the Internet on this process consists on providing better information and knowledge to all members of the supply chain involved in this process.

Another impact of the Internet on the returns process is related with e-commerce. Ecommerce generates more returns than the traditional commerce (Gentry, 1999; Meyer, 1999). Handling these returns efficiently is, without any question, an important issue for companies selling through the Internet. Not only because the volume of returns is higher in the e-commerce than in the traditional channel, but also because the logistics involved is different. For example, in the traditional commerce, a customer that wants to return a product (within a few days of having bought it) he just has to go back to the store and return it. On the Internet channel this is different: How should the product be returned? Who should pay for this return? And, what should be the best supply chain structure to recover these products efficiently? It is not clear that the same structures of the direct supply chain should be used. Designing efficient close-loop supply chains is a key element to improve the reverse logistics and returns process, and the Internet can play an important role on this aspect.

In the literature review regarding this process, the existing papers cover both types of impact: sharing information through the Internet and returns of e-commerce sales. Spengler and Schröter (2003) provide a case study to show how an Internet tool can be used to provide information to all members of the supply chain involved in the returns process. van Nunen and Zuidwijk (2004) describe the impact of information and communication technology, including the Internet, on the three perspectives of a Close-Loop Supply Chains: processes, products and customers. Vlachos and Dekker (2003) provide a mathematical model to better manage the returns for Internet sales, and Mukhopadhyay and Setoputro (2004) analyse, for eretailing businesses, the trade off between the increased revenue due a generous returns policy and the increased cost due the increased quantity of products return.

In the next future, we expect the development of decision models to solve the problems related to the huge amount of returns associated with e-commerce. Some lines of further 
research are: the dynamic estimation of expected demand of serviceable returns (Vlachos and Dekker, 2003), inventory models considering returns, production planning including recoverable parts and assemblies (Soto and Lourenço, 2002), routing and distribution systems to handle returns, etc. Also, the possibility of sharing, through the web, information related to the returns puts more emphasis on developing analytical tools to help decision makers. More studies like the one provided by Spengler and Schröter (2003) are expected. Finally, researchers should also focus on the design of closed-loop supply chains that make use of the Internet to manage efficiently the recovery of the return products, as the work of van Nunen and Zuidwijk (2004) does.

\subsection{Impact of the Internet on several supply chain processes}

Under this heading we have classified all the papers which aim is to analyse the impact of the Internet on several supply chain processes. Seven papers have been classified into this category. Gunasekaran, Marri et al. (2002) and Sarkis, Meade et al. (2004) are conceptual papers. Gunasekaran, Marri et al. (2002) define e-commerce and examine its application in manufacturing, retailing and service operations. Sarkis, Meade et al. (2004) focus on a discussion of forward and reverse e-logistics and their relationship to the natural environment.

Cagliano, Caniato et al. (2003), Muffatto and Payaro (2004) and Croom (2005) are empirically based papers. Cagliano, Caniato et al. (2003) explore the actual adoption of Internet technologies in several supply chain processes by a large sample of European manufacturing firms. And in 2005 they provide an update of the previous paper (see Cagliano, Caniato et al., 2005). Muffatto and Payaro (2004) analyse the benefits achieved in the procurement and fulfilment processes as a result of the Internet usage in these processes. Croom (2005) through an interview study with a large sample of organisations analyses the impact of e-business on supply chain strategy, examining three representative areas of SCM: the procurement, CRM and fulfilment processes.

The paper of Robinson, Sahin et al. (2005) is a simulation-based paper which aim is to investigate the impact of electronic replenishment (the seamless automation of the buyer's procurement and vendor's fulfilment processes) on the operational activities and performance of a make-to-order supply chain.

Johnson and Whang (2002) and Gunasekaran and Ngai (2004) conduct a literature review. Johnson and Whang (2002) examine how the web is changing SCM and classify the papers into three main categories: e-commerce, e-procurement and e-collaboration. Gunasekaran and Ngai (2004) conduct a literature review focusing on the role and implications of IT in SCM. They classified the papers according to what they called the major components of IT-enabled SCM: strategic planning for IT in SCM, virtual enterprise and SCM, e-commerce and SCM, infrastructure for IT in SCM, Knowledge and IT management in SCM, and implementation of IT in SCM.

Our paper follows the same methodology as Johnson and Whang (2002) and Gunasekaran and Ngai (2004), but it differs from them in the classification scheme and the framework used to classify the papers. We have classified the papers using a framework based on the idea that SCM is the management of supply chain processes. As Croom (2005) pointed out very recently, there is some debate about the scope of SCM and one way of dealing with the diversity of SCM definitions is to concentrate on the core processes and functions relating to the management of supply chains (for example, fulfilment, operations planning and procurement). 
We defined e-SCM as the impact of the Internet on the integration of key business processes. Future studies should investigate the adoption of Internet enabling tools to facilitate integration along the supply chain. Some aspects to be studied are: in which processes is the Internet most used to integrate with other functional areas and/or supply chain members? In case of differences between processes, which are the reasons of these differences in the level of implementation of Internet enabling tools? Which are the benefits that companies are achieving with the implementation of the Internet in different supply chain processes? We expect more research on this area. In fact, the papers analysing the impact of the Internet on several supply chain processes have been published very recently.

\section{Conclusions}

It has been demonstrated that the Internet can have an important impact on the management of the supply chain and it can improve the competitiveness of firms. With the development of web-technologies, SCM will focus on helping decision makers better manage customer relationships, efficiently integrate internal processes and collaborate in real time with trading partners. In terms of managing customer relationships the Internet represents an efficient mean to communicate with customers. In the future we will see more companies collecting data as users navigate around their web-pages. In this sense, the Internet can generate a large amount of data, which can be very useful to CRM if analysed properly. In terms of integrating internal processes and with other trading partners, we will see how the Internet is a key enabler of integrative practices such as vendor managed inventory and CPFR.

The literature review undertaken on the topic has shown that e-SCM has been acknowledged as an outstanding topic in the supply chain literature in the most prestigious Operations Management and Logistics journals, especially after year 2000. However, our literature review has shown that there is a disjointed scattering of research activity that fails to clearly represent what we currently know about the effects of the Internet on SCM and what we still need to learn. In this paper we have attempted (1) to describe the impact that the Internet has on the different supply chain processes, (2) to review the existing literature on the topic, (3) to provide a framework for the analysis of e-SCM, and (4) to identify further lines of research.

Although the literature review is not exhaustive (other management journals should have also been reviewed, such as Marketing and Information Systems journals), it serves as comprehensive base for understanding the impact of the Internet on SCM. Our paper has followed the same methodology as the literature reviews of Johnson and Whang (2002) and Gunasekaran and Ngai (2004), but it differs from them on the objectives established and the results achieved. Johnson and Whang (2002) explored how e-business was changing the supply chain and examined the rapidly evolving research in this area. They classified 30 papers into three categories: e-commerce, e-procurement and e-collaboration. They provided a summary of what these papers were covering but they did not identify further lines of research. Gunasekaran and Ngai (2004) reviewed 114 papers on IT in SCM and elaborated a framework for the development and implementation of IT in SCM. This literature review had the objective of classifying the papers to bring out pertinent factors that would support practitioners in their effort to achieve an IT-enabled SCM. They also provided some lines or further research for academicians. Our paper, as the Gunasekaran and Ngai (2004) paper, provides a framework to classify the existing research and identifies some lines of further research. One of the key contributions of our paper is that it presents a framework based on the idea that SCM is the management of key business processes, which has been recently adopted by many researchers (see for example, Romano and Vinelli, 2001; Cagliano, Caniato 
et al., 2003; Mills, Schmitz et al., 2004; Cousins, 2005; Croom, 2005; and Danese, Romano et al., 2006).

We believe that this paper will be very helpful for practitioners and academicians. Practitioners are provided with some insights regarding which are the main effects of the Internet on SCM and which sources can be consulted in case of being interested in obtaining a deeper knowledge of the impact of the Internet in a specific area (for, example, a practitioner interested in adopting an e-procurement tool can review the papers classified under this topic). Researchers are given a framework that classifies the existing literature. The value of this framework is a tool to help researchers synthesise the volume and breadth on what has been done on e-SCM. Researchers are also given some lines of further research.

We expect that the number of research papers in this area will increase significantly in the next years, given the increased interest in SCM and the Internet by academicians and practitioners. Some directions for further research that we have identified are: to conduct empirical studies about the impact of the Internet on several SCM processes, such as the reverse and the demand management processes which, so far, have been only considered by a couple of authors. Further research should also put more emphasis on conducting empirical studies regarding the implementation of the Internet in the product development process. Although e-fulfilment has been one of the most covered topics there are still some further lines of research in this area: to study new strategies to respond to the challenge of the last mile problem, and to conduct more empirical studies to explore what companies are doing to respond to this challenge and what are the results of the different actions taken. Eprocurement has been the most covered topic, especially the subtopics related with marketplaces and auctions. However, we identified some lines of further research related with this topic: to investigate the benefits and barriers of B2B procurement, and to analyse how to strategically segment e-procurement strategies.

\section{References}

Abid, C., D'amours, S. and Montreuil B. (2004), "Collaborative order management in distributed manufacturing", International Journal of Production Research, Vol. 42 No. 2, pp. 283-302.

Agarwal, A. and Shankar, R. (2003), "Online trust building in e-enabled supply chain", Supply Chain Management: An International Journal, Vol. 8 No. 4, pp. 324-334.

Agi, M., Ballot, E. and Molet, H. (2005), "100\% EDI-connected suppliers projects: An empirical investigation of success factors", Journal of Purchasing and Supply Management, Vol. 11 No. 2-3, pp. 107-115.

Alfaro, J. A., Alvarez, M. J. and Montes, M. J. (2002), "Lagging behind versus advancing too fast? Identifying gaps research in Supply Chain", $9^{\text {th }}$ Annual Meeting of the European Operations Management Association (EUROMA), Copenhagen, Denmark.

Alptekinoglu, A. and Tang, C. S. (2005), "A model for analyzing multi-channel distribution systems", European Journal of Operational Research, Vol. 163 No. 3, pp. 802-824.

Auramo, J., Kauremaa, J. and Tanskanen, K. (2005), "Benefits of IT in supply chain management: An explorative study of progressive companies", International Journal of Physical Distribution \& Logistics Management, Vol. 35 No. 2, pp. 82-100.

Bal, J., Wilding, R. and Gundry, J. (1999), "Virtual teaming in the agile supply chain", The International Journal of Logistics Management, Vol. 10 No. 2, pp. 71-82. 
Bapna, R., Goes, P. and Gupta, A. (2003), "Analysis and design of business-to-consumer online auctions", Management Science, Vol. 49 No. 1, pp. 85-101.

Barratt, M. and Rosdahl, K. (2002), "Exploring business-to-business marketsites", European Journal of Purchasing \& Supply Management, Vol. 8 No. 2, pp. 111-122.

Bartezzaghi, E. and Ronchi, S. (2004), "A portfolio approach in the e-purchasing of materials", Journal of Purchasing and Supply Management, Vol. 10 No. 3, pp. 117-126.

Bendoly, E. and Schoenherr, T. (2005), "ERP system and implementation-process benefits: Implications for B2B e-procurement", International Journal of Operations \& Production Management, Vol. 25 No. 4, pp. 304-319.

Biehl, M. (2005), "Selecting internal and external supply chain functionality: The case of ERP systems versus electronic marketplaces", Journal of Enterprise Information Management, Vol. 18 No. 4, pp. 441 - 457.

Boyd, S. L., Hobbs, J. E. and Kerr, W. A. (2003), "The impact of customs procedures on business to consumer e-commerce in food products", Supply Chain Management: An International Journal, Vol. 8 No. 3, pp. 195-200.

Boyer, K. K., Hallowell, R. and Roth, A. V. (2002), "E-services: Operating strategy - A case study and a method for analyzing operational benefits", Journal of Operations Management, Vol. 20 No. 2, pp. 175-189.

Boyer, K. K. and Hult, G. T. M. (2005), "Extending the supply chain: Integrating operations and marketing in the online grocery industry", Journal of Operations Management, Vol. 23 No. 6, pp. 642-661.

Boyer, K. K. and Olson, J. R. (2002), "Drivers of Internet purchasing success", Production and Operations Management, Vol. 11 No. 4, pp. 480-498.

Brenner, W. and Hamm, V. (1996), "Information technology for purchasing in a process environment", European Journal of Purchasing \& Supply Management, Vol. 2 No.4, pp. 211219.

Bruun, P. and Mefford, R. N. (2004), "Lean production and the Internet", International Journal of Production Economics, Vol. 89 No. 3, pp. 247-260.

Burke, G. J. and Vakkaria, A. J. (2002), Supply Chain Management. Internet encyclopedia. John Wiley, New York.

Cagliano, R., Caniato, F. and Spina, G. (2003), "E-business strategy: How companies are shaping their supply chain through the Internet", International Journal of Operations \& Production Management, Vol. 23 No. 10, pp. 1142-1162.

Cagliano, R., Caniato, F. and Spina, G. (2005), "E-business strategy: How companies are shaping their supply chain through the Internet", International Journal of Operations \& Production Management, Vol. 25 No.12, pp. 1309-1327.

Calosso, T., Cantamessa, M., Vu, D. and Villa, A. (2003), "Production planning and order acceptance in business electronic commerce", International Journal of Production Economics, Vol. 85 No. 2, pp. 233-249.

Caputo, A. C., Cucchiella, F., Fratocchi, L. and Pelagagge, P. M. (2005), "An integrated framework for e-supply networks analysis", Supply Chain Management: An International Journal, Vol. 10 No. 2, pp. 84 - 95. 
Carare, O. and Rothkopf, M. (2005), "Slow Dutch auctions", Management Science, Vol. 51 No. 3, pp. 365-373.

Carr, S. M. (2003), "Note on online auctions with costly bid evaluation", Management Science, Vol. 49 No. 11, pp. 1521-1529.

Cassivi, L., Lefebvre, E., Lefebvre, L. A. and Leger, P. M. (2004), "The Impact of Ecollaboration Tools on Firms' Performance", The International Journal of Logistics Management, Vol. 15 No.1, pp. 91-110.

Chan, M. F. S. and Chung, W. W. C. (2002), "A framework to develop an enterprise information portal for contract manufacturing", International Journal of Production Economics, Vol. 75, pp. 113-126.

Cheng, K., Pan, P. Y. and Harrison, D. K. (2000), "The Internet as a tool with application to agile manufacturing: A web-based engineering approach and its implementation issues", International Journal of Production Research, Vol. 38 No. 12, pp. 2743-2759.

Cheng, K., Webb, D. and Marsh, R. (Eds.) (2004), Advances in e-engineering and digital enterprise technology, Professional Engineering Publishing, London.

Cheng, K. (Ed.) (2005), E-manufacturing: Fundamentals and Applications, WIT Press, London.

Chou, D. C., Tan, X. and Yen, D. C. (2004), "Web technology and supply chain management", Information Management \& Computer Security, Vol. 12 No.4, pp. 338-349.

Christopher, M. (1998), Logistics and supply chain management: Strategies for reducing cost and improving service, Financial Times Pitman Publishing, London.

Clarke, M. P. (1998), "Virtual logistics: An introduction and overview of the concepts", International Journal of Physical Distribution \& Logistics Management, Vol. 28 No. 7, pp. 486-507.

Cohen, M., Kelly, C. B. and Medaglia, A. L. (2001), "Decision support with web-enabled software", Interfaces, Vol. 31 No. 2, pp. 109-129.

Cooper, M. C., Lambert, D. M. and Pagh , J. D. (1997), "Supply chain management: More than a new name for logistics", The International Journal of Logistics Management, Vol. 8 No. 1, pp. 1-13.

Cousins, P. D. (2005), "The alignment pf appropriate firm and supply strategies for competitive advantages", International Journal of Operations \& Production Management, Vol. 25 No. 5, pp. 403-428.

Croom, S. R. (2000), "The impact of web-based procurement on the management of operating resources supply", The Journal of Supply Chain Management, Vol. 36 No. 1, pp. 4-13.

Croom, S. R. (2005), "The impact of e-business on supply chain management", International Journal of Operations \& Production Management, Vol. 25 No. 1, pp. 55-73.

Crowley, J. A. (1998), "Virtual logistics: Transport in the marketspace", International Journal of Physical Distribution \& Logistics Management, Vol. 28 No. 7, pp. 547-574.

Croxton, K. L., García-Dastugue, S. J., Lambert, D. M. and Rogers, D. S. (2001), "The supply chain management processes", The International Journal of Logistics Management, Vol. 12 No. 2, pp. 13-36. 
Da Silveira, G. J. C. (2003), "Towards a framework for operations management in ecommerce", International Journal of Operations \& Production Management, Vol. 23 No.2, pp. 200-212.

Dadzie, K. Q., Chelariu, C. and Winston, E. (2005), "Customer service in Internet-enabled logistics supply chain: website design antecedents and loyalty effects", Journal of Business Logistics, Vol. 26 No. 1, pp. 53-78.

Danese, P., Romano, P. and Vinelli, A. (2006), "Sequences of improvements in supply networks: case studies from pharmaceuticall industry", International Journal of Operations \& Production Management, Vol. 26 No. 11, pp. 1199-1222.

Davenport, T. H. and Brooks, J. D. (2004), "Enterprise systems and the supply chain", Journal of Enterprise Information Management, Vol. 17 No. 1, pp. 8-19.

De Boer, L., Harink, J. and Heijboer G. (2002), "A conceptual model for assessing the impact of electronic procurement", European Journal of Purchasing \& Supply Management, Vol. 8 No.1, pp. 25-33.

De Burca, S., Fynes, B. and Marshall, D. (2005), "Strategic technology adoption: extending ERP across the supply chain", Journal of Enterprise Information Management, Vol. 18 No.4, pp. 427-440.

Dedrick, J. and Kraemer, K. L. (2005), "The impacts of IT on firm and industry structure: The personal computer industry", California Management Review, Vol. 47 No. 3, pp. 122-142.

Deeter-Schmelz, D. R., Bizzari, A., Graham, R. and Howdyshell, C. (2001), "Business-toBusiness online purchasing: Suppliers' impact on buyers' adoption and usage intent", The Journal of Supply Chain Management, Vol. 37 No.1, pp. 4-10.

Delfmann, W., Albers, S. and Gehring, M. (2002), "The impact of e-commerce on logistics service providers", International Journal of Physical Distribution \& Logistics Management, Vol. 32 No. 3, pp. 203-222.

Deltas, G. and Engelbrecht-Wiggans, R. (2005), "Naive bidding", Management Science, Vol. 51 No. 3, pp. 328-338.

Dewman, R., Freimer, M. and Seidmann, A. (2000), "Organizing distribution channels for information goods on the Internet", Management Science, Vol. 46 No. 4, pp. 483-495.

Ding, M., Eliashberg, J., Huber, J. and Saini, R. (2005), "Emotional bidders -An analytical and experimental examination of consumers' behavior in a priceline-like reverse auction", Management Science, Vol. 51 No. 3, pp. 352-364.

Disney, S. M., Naim, M. M. and Potter, A. (2004), "Assessing the impact of e-business on supply chain dynamics", International Journal of Production Economics, Vol. 89 No. 2, pp. 109-118.

Donohue, J. M. and Fox, J. B. (2000), "A multiple-method evaluation of journals in decision and management sciences by US academics", Omega, Vol. 28 No. 1, pp. 17-36.

Easley, R. F. and Tenorio, R. (2004), "Jump bidding strategies in Internet auctions", Management Science, Vol. 50 No.10, pp. 1407-1419.

Elliman, T. and Orange, G. (2000), "E-commerce to support construction design and supplychain management: A research note", International Journal of Physical Distribution \& Logistics Management, Vol. 30 No. 3/4, pp. 345-360. 
Ellinger, A. E., Lynch, D.F., Andzullis, J. and Smith, R. (2003), "B2B e-commerce: A content analytical assessment of motor carrier websities", Journal of Business Logistics, Vol. 24 No. 1, pp. 199-220.

Ellram, L. M. (1991), "Supply chain management: The industrial organization perspective", International Journal of Physical Distribution \& Logistics Management, Vol. 21 No.1, pp. 13-22.

Emiliani, M. L. (2000), "B2B online auctions: Key issues for purchasing process improvement", Supply Chain Management: An International Journal, Vol. 5 No. 4, pp.176186.

Emiliani, M. L. and Stec, D. J. (2002a), "Realizing savings from online reverse auctions", Supply Chain Management: An International Journal, Vol. 7 No.1, pp. 12-23.

Emiliani, M. L. and Stec, D. J. (2002b), "Squaring online reverse auctions with the caux round table principles for business", Supply Chain Management: An International Journal, Vol. 7 No.2, pp. 92-100.

Emiliani, M. L. and Stec, D. J. (2004), "Aerospace parts suppliers' reaction to online reverse auctions", Supply Chain Management: An International Journal, Vol. 9 No. 2, pp. 139-153.

Eng, T. Y. (2005), "The influence of a firm's cross-functional orientation on supply chain performance", The Journal of Supply Chain Management, Vol. 41 No.4, pp. 4-16.

Essig, M. and Arnold, U. (2001), "Electronic procurement in supply chain management: An information economics-based analysis of electronic markets", The Journal of Supply Chain Management, Vol. 37 No.4, pp. 43-49.

Finch, B. J. (1999), "Internet discussions as a source for consumer product customer involvement and quality information: An exploratory study", Journal of Operations Management, Vol. 17 No. 5, pp. 535-557.

Frohlich, M. T. (2002), "E-integration in the supply chain: Barriers and performance", Decision Sciences, Vol. 33 No. 4, pp. 537-556.

Frohlich, M. T. and Westbrook, R. (2002), "Demand chain management in manufacturing and services: web-based integration, drivers and performance", Journal of Operations Management, Vol. 20 No. 6, pp. 729-745.

Gaur, V., Giloni, A. and Seshadri, S. (2005), "Information sharing in a supply chain under ARMA demand", Management Science, Vol. 51 No. 6, pp. 961-969.

Gentry, C. R. (1999), "Reducing the cost of returns", Chain Store Age, Vol. 75 No.10, pp. 124-126.

Geoffrion, A. M. and Krishnan, R. (2001), "Prospect for operations research in the e-business era", Interfaces, Vol. 31 No. 2, pp. 6-36.

Geunes, J., Akcali, E., Pardalos, P. M., Romeijn, H. E. and Shen, Z. J. (Eds.) (2005), Applications of supply chain management and e-commerce research, Springer.

Goh, C. H., Holsapple, C. W., Johnson L. E., and Tanner J. R. (1997), "Evaluating and classifying POM journals", Journal of Operations Management, Vol. 15 No. 2, pp. 123-138.

Golicic, S. L., Davis, D. F., McCarthy, T. M. and Mentzer, J. T. (2002), "The impact of ecommerce on supply chain relationships", International Journal of Physical Distribution \& Logistics Management, Vol. 32 No. 10, pp. 851-871. 
Graham, G., Burnes, B., Lewis, J. G. and Langer, J. (2004), "The transformation of the music industry supply chain", International Journal of Operations \& Production Management, Vol. 24 No. 11, pp. 1087-1103.

Graham, G. and Hardaker, G. (2000), "Supply chain management across the Internet", International Journal of Physical Distribution \& Logistics Management, Vol. 30 No. 3/4, pp. 286-295.

Granot, D. and Sošic, G. (2005), "Formation of alliances in internet-based supply exchanges", Management Science, Vol. 51 No. 1, pp. 92-105.

Greis, N. P. and Kasarda, J. D. (1997), "Enterprise logistics in the information era", California Management Review, Vol. 39 No. 4, pp. 55-78.

Grieger, M. (2003), "Electronic marketplaces: A literature review and a call for supply chain management review", European Journal of Operational Research, Vol. 144 No. 2, pp. 280294.

Gudmundsson, S. V. and Walczuck, R. (1999), "The development of electronic markets in logistics", The International Journal of Logistics Management, Vol. 10 No.2, pp. 99-113.

Gunasekaran, A., Marri, H. B., McGaughey, R. E. and Nebhwani, M. D. (2002), "Ecommerce and its impact on operations management", International Journal of Production Economics, Vol. 75 No. 1/2, pp. 185-198.

Gunasekaran, A. and Ngai, E. W. T. (2004), "Information systems in supply chain integration and management", European Journal of Operational Research, Vol. 159 No. 2, pp. 269-295.

Gunluk, O., Ladányi, L. and De Vries, S. (2005), "A branch-and-price algorithm and new test problems for spectrum auctions", Management Science, Vol. 51 No.3, pp.391-406.

Gurãu, C., Ranchhod, A. and Hackney, R. (2001), "Internet transactions and physical logistics: Conflict or complementary?", Logistics Information Management, Vol. 14 No. 1/2, pp. 33-43.

Harland, C. M. (1996), "Supply chain management: Relationships, chains and networks", British Journal of Management, Vol. 7 Special Issue, pp. S63-S80.

Hayes, J. and Finnegan, P. (2005), "Assessing the potential of e-business models: towards a framework for assisting decision-makers", European Journal of Operational Research, Vol. 160 No. 2, pp. 365-379.

Hazra, J., Mahadevan, B. and Seshadri, S. (2004), "Capacity allocation among multiple suppliers in an electronic market", Production and Operations Management, Vol. 13 No. 2, pp. 161-170.

Hewitt, F. (1994), "Supply chain redesign", The International Journal of Logistics Management, Vol. 5 No. 2, pp. 1-9.

Hohner, G., Rich, J., Ng, E., Reid, G., Davenport, A. J., Kalagnanam, J. R., Lee, H. S. and an, C. (2003), "Combinatorial and quantity-discount procurement auctions benefit Mars, incorporated and its suppliers", Interfaces, Vol. 33 No. 1, pp. 23-35.

Houlihan, J. (1984), "Supply chain management", Proceedings of the 19th International Technical Conference, BPICS, pp. 101-110.

Iyer, K. N. S., Germain, R. and Frankwick, G. L. (2004), "Supply chain B2B e-commerce and time-based delivery performance", International Journal of Physical Distribution \& Logistics Management, Vol. 34 No. 8, pp. 645-661. 
James, M., Grosvenor, R. and Prickett, P. (2004), "e-distribution: Internet-based management of a merchandiser supply chain", Supply Chain Management: An International Journal, Vol. 9 No. 1, pp. 7 - 15.

Jap, S. and Mohr, J. J. (2002), "Leveraging Internet technologies in B2B relationships", California Management Review, Vol. 44 No. 4, pp. 24-38.

Johnson, M. E. and Whang, S. (2002), "E-business and supply chain management: An overview and framework", Production and Operations Management, Vol. 11 No. 4, pp. 413423.

Joo, Y. B. and Kim, Y. G. (2004), "Determinants of corporate adoption of e-marketplace: An innovation theory perspective", Journal of Purchasing and Supply Management, Vol. 10 No. 2, pp. 89-101.

Jouenne, T. (2000), "Henkel-Eroski CPFR pilot case study", CPFR White Paper (www.cpfr.org).

Kämäräinen, V. (2001), "The reception box impact on home delivery efficiency in the egrocery business", International Journal of Physical Distribution \& Logistics Management, Vol. 31 No. 6, pp. 414-426.

Kaplan, S. and Sawhney, M. (2000), "E-Hubs: The new B2B marketplaces", Harvard Business Review, Vol. 78 No. 3, pp. 97-103.

Kaufmann, L. and Carter, C. R. (2002), "International supply management systems. The impact of price vs. non-price driven motives in the United States and Germany", The Journal of Supply Chain Management, Vol. 38 No. 3, pp. 4-17.

Keenan, F. and Ante, S. (2002), "The new teamwork", Business Week, 18 February.

Kehoe, D. F. and Boughton, N. J. (2001a), "New paradigms in planning and control across manufacturing supply chain", International Journal of Operations \& Production Management, Vol. 21 No. 5/6, pp. 582-593.

Kehoe, D. F. and Boughton, N. J. (2001b), "Internet based supply chain management: A classification of approaches to manufacturing planning and control", International Journal of Operations \& Production Management, Vol. 21 No. 4, pp. 516-524.

Kelleher, G., El-Rahalibi, A. and Arshad, F. (2003), "Scheduling for intermodal transport", Logistics Information Management, Vol. 16 No. 5, pp. 363-372.

Keskinocak, P. and Tayur, S. R. (2001), "Quantitative analysis for Internet-enabled supply chains", Interfaces, Vol. 31 No. 2, pp. 70-89.

Kevin Chiang, W. Y. and Monahan, G. E. (2005), "Managing inventories in a two-echelon dual-channel supply chain", European Journal of Operational Research, Vol. 162 No.2, pp. 325-341.

Kleindorfer, P. R. and Wu, D. J. (2003), "Integrating long- and short-term contracting via Business-to-Business exchanges for capital intensive industries", Management Science, Vol. 49 No.11, pp. 1597-1615.

Knudsen, D. (2003), "Aligning corporate strategy, procurement strategy and e-procurement tools", International Journal of Physical Distribution \& Logistics Management, Vol. 33 No. 8, pp. 720-734. 
Ko, C. S., Kim, T. and Hwang, H. (2001), "External partner selection using Tabu search heuristics in distributed manufacturing", International Journal of Production Research, Vol. 39 No. 17, pp. 3959-3974.

Kotzab, H. and Madlberger, M. (2001), "European retailing in e-transition? An empirical evaluation of web-based retailing - Indications from Austria", International Journal of Physical Distribution \& Logistics Management, Vol. 31 No. 6, pp. 440-462.

Larson, P. D., Carr, P. and Dhariwal, K. (2005), "SCM involving small versus large suppliers: Relational exchange and electronic communication media", The Journal of Supply Chain Management, Vol. 41 No. 1, pp. 18-29.

Lee, H. L. (2002), "Aligning supply chain strategies with product uncertainties", California Management Review, Vol. 44 No. 3, pp. 105-119.

Lee, H. L. and Whang, S. (2001), "Winning the last mile of e-commerce", Sloan Management Review, Vol. 42 No. 4, pp. 54-62.

Lee, H. L. and Whang, S. (2002), "The impact of secondary market on the supply chain", Management Science, Vol. 48 No. 6, pp. 719-731.

Lee, Y. M. and Chen, E. J. (2002), "BASF uses framework for developing web-based production-planning-optimization tools", Interfaces, Vol. 32 No. 6, pp.15-24.

Lewis, G. J., Graham, G. and Hardaker, G. (2005), "Evaluating the impact of the internet on barriers to entry in the music industry", Supply Chain Management: An International Journal, Vol. 10 No. 5, pp. 349-356.

Lewis, I. and Talalayevsky, A. (2004), "Improving the interorganizational supply chain through optimization of information flows", Journal of Enterprise Information Management, Vol. 17 No. 3, pp. 229-237.

Lyons, A. C., Coronado Mondragon, A. E., Bremang, A., Kehoe, D. F. and Coleman, J. (2005), "Prototyping an information system's requirements architecture for customer-driven, supply-chain operations", International Journal of Production Research, Vol. 43 No.20, pp. 4289-4319.

Mahadevan, B. (2000), "Business models for Internet-based e-commerce: An anatomy", California Management Review, Vol. 42 No.4, pp. 55-69.

Mahadevan, B. (2003), "Making sense of emerging market structures in B2B e-commerce", California Management Review, Vol. 46 No.1, pp. 86-100.

Marinus, R. and De Koster, R. M. (2002), "Distribution structures for food home shopping", International Journal of Physical Distribution \& Logistics Management, Vol. 32 No. 5, pp. 362-380.

McGuffog, T. and Wadsley, N. (1999), "The general principles of value chain management", Supply Chain Management: An International Journal, Vol. 4 No.5, pp. 218-225.

Mclvor, R. and Humphreys, P. (2004), "The implications of electronic B2B intermediaries for the buyer-supplier interface", International Journal of Operations \& Production Management, Vol. 24 No. 3, pp. 241-269.

Metty, T., Harlan, R., Samelson, Q., Moore, T., Morris, T., Sorensen, R., Schneur, A., Raskina, O., Schneur, R., Kanner, J., Potts, K. and Robbins, J. (2005), "Reinventing the supplier negotiation process at Motorola", Interfaces, Vol. 35 No. 1, pp. 7-23. 
Meyer, H. (1999), "Many happy returns", The Journal of Business Strategy, Vol. 20 No.4, pp. 27-31.

Mills, J., Schmitz, J. and Frizelle, G. (2004), "A strategic review of supply networks", International Journal of Operations \& Production Management, Vol. 24 No. 10, pp. 10121036.

Min, H. and Galle, W. P. (1999), "E-commerce usage in B2B purchasing", International Journal of Operations \& Production Management, Vol. 19 No. 9, pp. 909-921.

Mondal, S. and Tiwari, M. K. (2003), "Formulation of mobile agents for integration of supply chain using the KLAIM concept", International Journal of Production Research, Vol. 41 No. 1, pp. 97-120.

Muffatto, M. and Payaro, A. (2004), "Implementation of e-procurement and e-fulfillment processes: A comparison of cases in the motorcycle industries", International Journal of Production Economics, Vol. 89 No. 3, pp. 339-351.

Mukhopadhyay, S. K. and Setoputro, R. (2004), "Reverse logistics in e-business: Optimal price and return policy", International Journal of Physical Distribution \& Logistics Management, Vol. 34 No. 1, pp. 70-88.

Nagurney, A., Cruz, J., Dong, J. and Zhang, D. (2005), "Supply chain networks, electronic commerce, and supply side and demand side risk", European Journal of Operational Research, Vol. 164 No. 1, pp. 120-142.

Nair, A. (2005), "Emerging internet-enabled auction mechanisms in supply chain", Supply Chain Management: An International Journal, Vol. 10 No. 3, pp. 162-168.

O'Keefe, M. (2001a), "Building intellectual capital in the supply chain - The role of ecommerce", Supply Chain Management: An International Journal, Vol. 6 No. 4, pp. 148-151.

O'Keeffe, M. (2001b), "Myths and realities of e-commerce in the perishable foods industries: Unleashing the power of reputation and relationship assets", Supply Chain Management: An International Journal, Vol. 6 No. 1, pp. 12-15.

Oliver, R. K. and Webber, M. D. (1992), "Supply chain management: Logistics catches up with strategy", in Christopher, M. (Ed.), Logistics: The Strategic Issues, Chapman \& Hall, London, pp. 63-75.

Olson, J. R. and Boyer, K. K. (2003), "Factors influencing the utilization of Internet purchasing in small organizations", Journal of Operations Management, Vol. 21 No. 2, pp. 225-245.

Ordanini, A. (2005), "The effects of participation on B2B exchanges: A resource-based view", California Management Review, Vol. 47 No. 2, pp. 97-113.

Pannirselvam, G. P., Ferguson, L. A., Ash, R. C. and Siferd, S. P. (1999), "Operations management research: An update for the 1990s", Journal of Operations Management, Vol. 18 No. 1, pp. 95-112.

Papathanassiou, E., Arkoumani, B. and Kardaras, D. (2003), "Management context and impact of e-commerce in the Greek food industries", Logistics Information Management, Vol. 16 No. 2, pp. 134-144.

Parente, D. H., Venkataraman, R., Fizel, J. and Millet, I. (2004), "A conceptual research framework for analyzing online auctions in a B2B environment", Supply Chain Management: An International Journal, Vol. 9 No. 4, pp. 287 - 294. 
Peleg, B., Lee, H. L. and Hausman, W. H. (2002), "Short-term e-procurement strategies versus long-term contracts", Production and Operations Management, Vol. 11 No. 4, pp. 458479.

Pinker, E. J., Seidmann, A. and Vakrat, Y. (2003), "Managing online auctions: current business and research issues", Management Science, Vol. 49 No. 11, pp. 1457-1485.

Piramuthu, S. (2005), "Knowledge-based framework for automated dynamic supply chain configuration", European Journal of Operational Research, Vol. 165 No. 1, pp. 219-230.

Power, D. (2005), "Determinants of business-to-business e-commerce implementation and performance: A structural model", Supply Chain Management: An International Journal, Vol. 10 No. 2, pp. 96-113.

Prasad, S. and Babbar, S. (2000), "International operations management research", Journal of Operations Management, Vol. 18 No. 2, pp. 209-247.

Punakivi, M., Yrjölä, H. and Holström, J. (2001), "Solving the last mile issue: Reception box or delivery box?", International Journal of Physical Distribution \& Logistics Management, Vol. 31 No. 6, pp. 427-439.

Rabinovich, E. (2004), "Internet retailing intermediation: A multilevel analysis of inventory Liquidity and fulfillment guarantees", Journal of Business Logistics, Vol. 25 No. 2, pp. 139169.

Rabinovich, E. (2005), "Consumner direct fulfillment performance in Internet retailing: Emergency transhipments and demand dispersion", Journal of Business Logistics, Vol. 26 No. 1, pp. 79-112.

Rabinovich, E. and Bailey, J. P. (2004), "Physical distribution service quality in Internet retailing: Service pricing, transaction attributes, and firm attributes", Journal of Operations Management, Vol. 21 No. 6, pp. 651-672.

Rabinovich, E. and Evers, P. T. (2003), "Product fulfillment in supply chains supporting Internet-retailing operations", Journal of Business Logistics, Vol. 24 No. 2, pp. 205-236.

Rae-Smith, J. B. and Ellinger, A. E. (2002), "Insights from the introduction of an online logistics service system", Supply Chain Management: An International Journal, Vol. 7 No. 1, pp. 5-11.

Richard, P. J. and Devinney, T. M. (2005), "Modular strategies: B2B technology and architectural knowledge", California Management Review, Vol. 47 No. 4, pp. 86-113.

Roberts, B. and Mackay, M. (1998), "IT supporting supplier relationships: The role of electronic commerce", European Journal of Purchasing \& Supply Management, Vol. 4 No. 2/3, pp. 175-184.

Robinson, E. P., Sahin, F. and Gao, L. (2005), "The impact of e-replenishment strategy on make-to-order supply chain performance", Decision Sciences, Vol. 36 No. 1, pp. 33-64.

Rogers, D. S. and Tibben-Lemke, R. S. (1999), Going Backwards: Reverse Logistics Trends and Practices, Reverse Logistics Executive Council Press, Pittsburgh.

Romano, P. and Vinelli, A. (2001), "Quality management in a supply chain perspective: Strategic and operative choices in a textile-apparel network", International Journal of Operations \& Production Management, Vol. 21 No. 4, pp. 446-460. 
Rubiano Ovalle, O. and Crespo Marquez, A. (2003), "The effectiveness of using ecollaboration tools in the supply chain: An assessment study with system dynamics", Journal of Purchasing and Supply Management, Vol. 9 No. 4, pp. 151-163.

Saeed, K. A., Malhotra, M. K. and Grover, V. (2005), "Examining the impact of interorganizational systems on process efficiency and sourcing leverage in buyer-supplier dyads", Decision Sciences, Vol. 36 No. 3, pp. 365-396.

Sarkis, J., Meade, L. M. and Talluri, S. (2004), "E-logistics and the natural environment", Supply Chain Management: An International Journal, Vol. 9 No. 4, pp. 303-312.

Sarkis, J. and Sundarraj, R. P. (2002), "Evolution of broking: Paradigms in e-commerce enabled manufacturing", International Journal of Production Economics, Vol. 75 No. 1/2, pp. 21-32.

Sarkis, J. and Talluri, S. (2004), "Evaluating and selecting e-commerce software and communication systems for a supply chain", European Journal of Operational Research, Vol. 159 No. 2, pp. 318-329.

Scott, C. H. and Scott, J. E. (2004), "On models for the operation of a class of electronic marketplaces", Omega, Vol. 32 No. 5, pp. 373-383.

Scullin, S. S., Fjermestad, J. and Romano, N. C. (2004). "E-relationship marketing: Changes in traditional marketing as an outcome of electronic customer relationship management", Journal of Enterprise Information Management, Vol. 17 No. 6, pp. 410-415.

Seifert, R. W., Thonemann, U. W. and Hausman, W. H. (2004), "Optimal procurement strategies for online spot markets", European Journal of Operational Research, Vol. 152 No. 3, pp. 781-799.

Shen, W., Kremer, R., Ulieru M. and Norrie D. (2003), "A collaborative agent-based infrastructure for Internet-enabled collaborative enterprises", International Journal of Production Research, Vol. 41 No. 8, pp. 1621-1639.

Simchi-Levi, D., Wu, S. D. and Shen, Z. J. (Eds.) (2004), Handbook of quantitative supply chain analysis: Modeling in the e-business era, Kluwer Academic Publishers.

Småros, J., Holmström, J. and Kämäräinen, V. (2000), "New service opportunities in the egrocery business", The International Journal of Logistics Management, Vol. 11 No. 1, pp. 6173.

Smart, A. (2005), "Exploring supply chain opportunities in the UK utilities sector and the supporting role of e-Marketplaces", Supply Chain Management: An International Journal, Vol. 10 No. 4, pp. 264-271.

Snir, E. M. and Hitt, L. M. (2003), "Costly bidding in online markets for IT services", Management Science, Vol. 49 No. 11, pp. 1504-1520.

Sodhi, M. S. (2001), "Applications and opportunities for operations research in Internetenabled supply chains and electronic marketplaces", Interfaces, Vol. 31 No. 2, pp. 56-69.

Soteriou, A. C., Hadjinicola, G. C. and Patsia, K. (1999), "Assessing production and operations management related journals: The European perspective", Journal of Operations Management, Vol. 17 No. 2, pp. 225-238.

Soto, J. P. and Lourenço, H. R. (2002), "A recoverable production planning model", working paper, Department of Economics and Business, Universitat Pompeu Fabra, Barcelona. 
Sparks, L. and Wagner, B. A. (2003), "Retail exchanges: A research agenda", Supply Chain Management: An International Journal, Vol. 8 No. 1, pp. 17-25.

Spengler, T. and Schröter, M. (2003), "Strategic management of spare parts in closed-loop supply chains -- A system dynamics approach", Interfaces, Vol. 33 No. 6, pp. 7-17.

Starr, M. K. (2003), "Application of POM to e-Business: B2C e-shopping", International Journal of Operations \& Production Management, Vol. 23 No. 1, pp. 105-124.

Stefansson, G. (2002), "Business-to-business data sharing: A source for integration of supply chain", International Journal of Production Economics, Vol. 75 No. 1, pp. 135-146.

Swaminathan, J. M. and Tayur, S. R. (2003), "Models for supply chains in e-Business", Management Science, Vol. 49 No. 10, pp. 1387-1406.

Talluri, S. and Ragazt, G. L. (2004), "Multi attribute reverse auctions in B2B exchanges: A framework for design and implementation", The Journal of Supply Chain Management, Vol. 40 No. 1, pp. 52-60.

Tatsiopoulos, I. P., Ponis, S. T., Hadzilias, E. A. and Panayiotou, N. A. (2002), "Realization of the virtual enterprise paradigm in the clothing industry through e-business technology", Production and Operations Management, Vol. 11 No. 4, pp. 516-530.

Teich, J. E., Wallenius, H., Wallenius, J. and Koppius, O. R. (2004), "Emerging multiple issue e-auctions", European Journal of Operational Research, Vol. 159 No. 1, pp. 1-16.

Themistocleous, M., Irani, Z. and Love, P. E. D. (2004), "Evaluating the integration of supply chain information systems: A case study", European Journal of Operational Research, Vol. 159 No. 2, pp. 393-405.

Thirumalai, S. and Sinha, K. K. (2005), "Customer satisfaction with order fulfillment in retail supply chains: Implications of product type in electronic B2C transactions", Journal of Operations Management, Vol. 23 No. 3-4, pp. 291-303.

Tsay, A. A. and Agrawal, N. (2004), "Channel conflict and coordination in the e-commerce age", Production and Operations Management, Vol. 13 No. 1, pp. 93-110.

Tsikriktsis, N., Lanzolla, G. and Frohlich, M. (2004), "Adoption of e-processes by service firms: An empirical study of antecedents", Production and Operations Management, Vol. 13 No. 3, pp. 216-229.

Tucker, D. and Jones, L. (2000), "Leveraging the power of the Internet for optimal supplier sourcing", International Journal of Physical Distribution \& Logistics Management, Vol. 30 No. 3/4, pp. 255-267.

Turowski, K. (2002), "Agent-based e-commerce in case of mass customization", International Journal of Production Economics, Vol. 75 No. 1, pp. 69-81.

Tyan, J. C., Wang, F. and Du, T. C. (2003), "An evaluation of freight consolidation policies in global third party logistics", Omega, Vol. 31 No. 1, pp. 55-62.

Upton, D. M. and McAfee, A. (1996), "The real virtual factory", Harvard Business Review, Vol. 74 No. 4, pp. 123-133.

Van Hoek, R. I. (2001), "E-supply chains - virtually non-existing", Supply Chain Management: An International Journal, Vol. 6 No. 1, pp. 21-28.

van Nunen, J. A. E. E. and Zuidwijk, R. A. (2004), "E-enabled closed-loop supply chains", California Management Review, Vol. 46 No. 2, pp. 40-54. 
Vannieuwenhuyse, B., Gelders, L. and Pintelon, L. (2003), "An online decision support system for transportation mode choice", Logistics Information Management, Vol. 16 No. 2, pp. 125-133.

Vastag, G. and Montabon, F. (2002), "Journal characteristics, ranking and social acculturation in operations management", Omega, Vol. 30 No. 2, pp. 109-126.

Vlachos, D. and Dekker, R. (2003), "Return handling options and order quantities for single period products", European Journal of Operational Research, Vol. 151 No. 1, pp. 38-53.

Vokurka, R. J. (1996), "The relative importance of journals in operations management research: A citation analysis", Journal of Operations Management, Vol. 14 No. 4, pp. 345355.

Wang, C. X. and Benaroch, M. (2004), "Supply chain coordination in buyer centric B2B electronic markets", International Journal of Production Economics, Vol. 92 No. 2, pp. 113124.

White, A. and Daniel, E. M. (2004), "The impact of e-marketplaces on dyadic buyer-supplier relationships: Evidence from the healthcare sector", Journal of Enterprise Information Management, Vol. 17 No. 6, pp. 441-453.

Wilson, T. P. and Clarke, W. R. (1998), "Food safety and traceability in the agricultural supply chain: Using the Internet to deliver traceability", Supply Chain Management: An International Journal, Vol. 3 No. 3, pp. 127-133.

Williams, L. R., Esper, T. L. and Ozment, J. (2002), "The e-supply chain: Its impact on the current and future structure of strategic alliances, partnerships and logistics leadership", International Journal of Physical Distribution \& Logistics Management, Vol. 32 No. 8, pp. 703-719.

Wise, R. and Morrison, D. (2000), "Beyond the exchange: The future of B2B", Harvard Business Review, Vol. 78 No. 6, pp. 86-96.

Wu, D. J. and Kleindorfer, P. R. (2005), "Competitive options, supply contracting, and electronic markets", Management Science, Vol. 51 No. 3, pp. 452-466.

Xie, S. Q., Tu, P. L., Aitchison, D., Dunlop, R. and Zhou Z. D. (2001), "A www-based integrated product development platform for sheet metal parts intelligent concurrent design and manufacturing", International Journal of Production Research, Vol. 39 No. 17, pp. 38293853.

Xie, S. Q., Tu, Y. L., Fung, R. Y. K. and Zhou, Z. D. (2003), "Rapid one-of-a-kind product development via the Internet: A literature review of the state-of-the-art and a proposed platform", International Journal of Production Research, Vol. 41 No. 18, pp. 4257-4299.

Xie, S. Q., Xu, X. and Tu, Y. L. (2005), "A reconfigurable platform in support of one-of-akind product development", International Journal of Production Research, Vol. 43 No. 9, pp. 1889-1910.

Xie, Y. and Salvendy, G. (2003), "Agent-based features for CAD browsers to foster engineering collaboration over the Internet", International Journal of Production Research, Vol. 41 No. 16, pp. 3809-3830.

Xiong, M., Tor, S. B., Khoo, L. P. and Chen C. H. (2003), "A web-enhanced dynamic BOMbased available-to-promise system", International Journal of Production Economics, Vol. 84 No. 2, pp. 133-148. 
Yeh, Y. P. (2005), "Identification of factors affecting continuity of cooperative electronic supply chain relationships: Empirical case of the Taiwanese motor industry", Supply Chain Management: An International Journal, Vol. 10 No. 4, pp. 327-335.

Yoo, S. B. and Kim, Y. (2002), "Web-based knowledge management for sharing product data in virtual enterprises", International Journal of Production Economics, Vol. 75 No. 1/2, pp. 173-184.

Yrjölä, H. (2001), "Physical distribution considerations for e-grocery shopping", International Journal of Physical Distribution \& Logistics Management, Vol. 31 No. 10, pp. 746-761.

Zhu, K. (2004), "Information transparency of business-to-business electronic markets: A game-theory analysis", Management Science, Vol. 50 No. 5, pp. 670-685. 
Table IA. Papers classified per topic and research methodology

\begin{tabular}{|c|c|c|c|}
\hline \multirow{2}{*}{ TOPIC } & \multicolumn{3}{|c|}{ Empirical } \\
\hline & Case Study & Survey & Web scan \\
\hline Customer relationship management & (Boyer, Hallowell et al., 2002) & (Tsikriktsis, Lanzolla et al., 2004) & \\
\hline Customer service management & (Rae-Smith and Ellinger, 2002) & (Papathanassiou, Kardaras et al., 2003) & (Ellinger, Lynch et al., 2003) \\
\hline \multicolumn{4}{|l|}{ Demand management } \\
\hline e-fulfilment & (Da Silveira, 2003; Starr, 2003) & $\begin{array}{l}\text { (Marinus and De Koster, 2002; Vannieuwenhuyse, } \\
\text { Gelders et al., 2003; Rabinovich, 2004; Rabinovich and } \\
\text { Bailey, 2004; Boyer and Hult, 2005; Dadzie, Chelariu } \\
\text { et al., 2005; Rabinovich, 2005; Thirumalai and Sinha, } \\
\text { 2005) }\end{array}$ & $\begin{array}{l}\text { (Gurãu, Ranchhod et al., 2001; Kotzab and } \\
\text { Madlberger, 2001) }\end{array}$ \\
\hline Manufacturing flow management & (Bruun and Mefford, 2004) & & \\
\hline e-procurement & (Kaufmann and Carter, 2002; Smart, 2005) & $\begin{array}{l}\text { (Min and Galle, 1999; Croom, 2000; Deeter-Schmelz, } \\
\text { Bizzari et al., 2001; Boyer and Olson, 2002; Olson and } \\
\text { Boyer, 2003; Bartezzaghi and Ronchi, 2004; Emiliani } \\
\text { and Stec, 2004; Joo and Kim, 2004; Ordanini, 2005; } \\
\text { Saeed, Malhotra et al., 2005) }\end{array}$ & (Mahadevan, 2003) \\
\hline $\begin{array}{l}\text { Product development and } \\
\text { commercialization }\end{array}$ & (Finch,1999; Xie, Xu et al., 2005) & & \\
\hline Reverse logistics and returns & (van Nunen and Zuidwijk, 2004) & & \\
\hline Several supply chain processes & (Muffatto and Payaro, 2004; Croom, 2005) & $\begin{array}{l}\text { (Cagliano, Caniato et al., 2003; Cagliano, Caniato et } \\
\text { al., 2005) }\end{array}$ & \\
\hline Supply chain relationships & $\begin{array}{l}\text { (Roberts and Mackay, 1998; Golicic, Davis et al., } \\
\text { 2002; White and Daniel, 2004) }\end{array}$ & (Yeh, 2005) & \\
\hline Information flows & $\begin{array}{l}\text { (Chan and Chung, 2002; Stefansson, 2002; } \\
\text { Tatsiopoulos, Ponis et al., 2002; Mondal and Tiwari, } \\
\text { 2003; James, Grosvenor et al., 2004; } \\
\text { Themistocleous, Irani et al., 2004; Bendoly and } \\
\text { Schoenherr, 2005; Biehl, 2005; De Burca, Fynes et } \\
\text { al., 2005; Lyons, Coronado Mondragon et al., 2005) }\end{array}$ & $\begin{array}{l}\text { (Bal, Wilding et al., 1999; Agi, Ballot et al., 2005; } \\
\text { Larson, Carr et al., 2005; Power, 2005) }\end{array}$ & \\
\hline \multicolumn{4}{|l|}{ Planning \& optimisation } \\
\hline $\begin{array}{l}\text { Industry structure and competitive } \\
\text { challenges }\end{array}$ & $\begin{array}{l}\text { (Graham, Burnes et al., 2004; Mclvor and } \\
\text { Humphreys, 2004; Dedrick and Kraemer, 2005; } \\
\text { Richard and Devinney, 2005) }\end{array}$ & & \\
\hline Impact on performance & (Cassivi, Lefebvre et al., 2004) & $\begin{array}{l}\text { (Frohlich, 2002; Frohlich and Westbrook, 2002; Iyer, } \\
\text { Germain et al., 2004; Auramo, Kauremaa et al., 2005; } \\
\text { Eng, 2005) }\end{array}$ & \\
\hline
\end{tabular}




\begin{tabular}{|c|c|c|c|}
\hline TOPIC & Literature Review & Conceptual and frameworks & Decision Models \\
\hline Customer relationship management & & (Småros, Holmström et al., 2000; Scullin, Fjermestad et al., 2004) & \\
\hline \multicolumn{4}{|l|}{ Customer service management } \\
\hline Demand management & & (McGuffog and Wadsley, 1999) & \\
\hline e-fulfilment & & $\begin{array}{l}\text { (Crowley, 1998; Yrjölä, 2001; Delfmann, Albers et al., 2002; Lee, 2002; } \\
\text { Boyd, Hobbs et al., 2003) }\end{array}$ & $\begin{array}{l}\text { (Dewman, Freimer et al., 2000; Kämäräinen, 2001; } \\
\text { Punakivi, Yrjölä et al., 2001; Kelleher, El-Rahalibi } \\
\text { et al., 2003; Rabinovich and Evers, 2003; Tyan, } \\
\text { Wang et al., 2003; Tsay and Agrawal, 2004; } \\
\text { Alptekinoglu and Tang, 2005; Kevin Chiang and } \\
\text { Monahan, 2005; Nagurney, Cruz et al., 2005; } \\
\text { Piramuthu, 2005) }\end{array}$ \\
\hline Manufacturing flow management & & (Kehoe and Boughton, 2001a; Kehoe and Boughton, 2001b) & $\begin{array}{l}\text { (Ko, Kim et al., 2001; Xiong, Tor et al., 2003; Abid, } \\
\text { D'amours et al., 2004) }\end{array}$ \\
\hline e-procurement & $\begin{array}{l}\text { (Grieger, 2003; Kleindorfer and } \\
\text { Wu, 2003; Teich, Wallenius et al., } \\
\text { 2004) }\end{array}$ & $\begin{array}{l}\text { (Brenner and Hamm, 1996; Gudmundsson and Walczuck, 1999; } \\
\text { Emiliani, 2000; Kaplan and Sawhney, 2000; Mahadevan, 2000; Tucker } \\
\text { and Jones, 2000; Wise and Morrison, 2000; Essig and Arnold, 2001; } \\
\text { Barratt and Rosdahl, 2002; de Boer, Harink et al., 2002; Emiliani and } \\
\text { Stec, 2002a; Emiliani and Stec, 2002b; Knudsen, 2003; Sparks and } \\
\text { Wagner, 2003; Parente, Venkataraman et al., 2004; Talluri and Ragazt, } \\
\text { 2004) }\end{array}$ & $\begin{array}{l}\text { (Lee and Whang, 2002; Peleg, Lee et al., 2002; } \\
\text { Bapna, Goes et al., 2003; Calosso, Cantamessa et al., } \\
\text { 2003; Carr, 2003; Hohner, Rich et al., 2003; Pinker, } \\
\text { Seidmann et al., 2003; Snir and Hitt, 2003; Easley } \\
\text { and Tenorio, 2004; Hazra, Mahadevan et al., 2004; } \\
\text { Scott and Scott, 2004; Seifert, Thonemann et al., } \\
\text { 2004; Wang and Benaroch, 2004; Carare and } \\
\text { Rothkopf, 2005; Deltas and Engelbrecht-Wiggans, } \\
\text { 2005; Ding, Eliashberg et al., 2005; Granot and } \\
\text { Sošic, 2005; Gunluk, Ladányi et al., 2005; Metty, } \\
\text { Harlan et al., 2005; Wu and Kleindorfer, 2005) }\end{array}$ \\
\hline $\begin{array}{l}\text { Product development and } \\
\text { commercialization }\end{array}$ & (Xie, Tu et al., 2003) & (Elliman and Orange, 2000) & $\begin{array}{l}\text { (Cheng, Pan et al., 2000; Xie, Tu et al., 2001; Xie } \\
\text { and Salvendy, 2003) }\end{array}$ \\
\hline Reverse logistics and returns & & & $\begin{array}{l}\text { (Spengler and Schröter, 2003; Vlachos and Dekker, } \\
\text { 2003; Mukhopadhyay and Setoputro, 2004) }\end{array}$ \\
\hline Several supply chain processes & $\begin{array}{l}\text { (Johnson and Whang, 2002; } \\
\text { Gunasekaran and Ngai, 2004) }\end{array}$ & (Gunasekaran, Marri et al., 2002; Sarkis, Meade et al., 2004) & (Robinson, Sahin et al., 2005) \\
\hline Supply chain relationships & & $\begin{array}{l}\text { (O'Keefe, 2001a; O'Keeffe, 2001b; Jap and Mohr, 2002; Williams, } \\
\text { Esper et al., 2002; Caputo, Cucchiella et al., 2005; Nair, 2005) }\end{array}$ & (Agarwal and Shankar, 2003) \\
\hline Information flows & & $\begin{array}{l}\text { (Upton and McAfee, 1996; Greis and Kasarda, 1997; Wilson and } \\
\text { Clarke, 1998; Van Hoek, 2001; Sarkis and Sundarraj, 2002; Turowski, } \\
\text { 2002; Davenport and Brooks, 2004; Lewis and Talalayevsky, 2004; } \\
\text { Hayes and Finnegan, 2005) }\end{array}$ & $\begin{array}{l}\text { (Yoo and Kim, 2002; Disney, Naim et al., 2004; } \\
\text { Sarkis and Talluri, 2004; Zhu, 2004; Gaur, Giloni et } \\
\text { al., 2005) }\end{array}$ \\
\hline Planning \& optimisation & (Swaminathan and Tayur, 2003) & $\begin{array}{l}\text { (Geoffrion and Krishnan, 2001; Keskinocak and Tayur, 2001; Sodhi, } \\
\text { 2001) }\end{array}$ & $\begin{array}{l}\text { (Cohen, Kelly et al., 2001; Lee and Chen, 2002; } \\
\text { Shen, Kremer et al., 2003) }\end{array}$ \\
\hline $\begin{array}{l}\text { Industry structure and competitive } \\
\text { challenges }\end{array}$ & & (Clarke, 1998; Graham and Hardaker, 2000; Lewis, Graham et al., 2005) & \\
\hline Impact on performance & & & (Rubiano Ovalle and Crespo Marquez, 2003) \\
\hline
\end{tabular}

